This item was submitted to Loughborough's Research Repository by the author.

Items in Figshare are protected by copyright, with all rights reserved, unless otherwise indicated.

\title{
Low energy refurbishment strategies for health buildings
}

PLEASE CITE THE PUBLISHED VERSION

http://www.tandfonline.com/doi/abs/10.1080/19401490903318218

\section{PUBLISHER}

Taylor and Francis (@ International Building Performance Simulation Association (IBPSA))

\section{VERSION}

AM (Accepted Manuscript)

\section{LICENCE}

CC BY-NC-ND 4.0

\section{REPOSITORY RECORD}

Short, C. Alan, Malcolm J. Cook, Paul C. Cropper, and Sura Al-Maiyah. 2019. "Low Energy Refurbishment Strategies for Health Buildings". figshare. https://hdl.handle.net/2134/8935. 
This item was submitted to Loughborough's Institutional Repository (https://dspace.lboro.ac.uk/) by the author and is made available under the following Creative Commons Licence conditions.

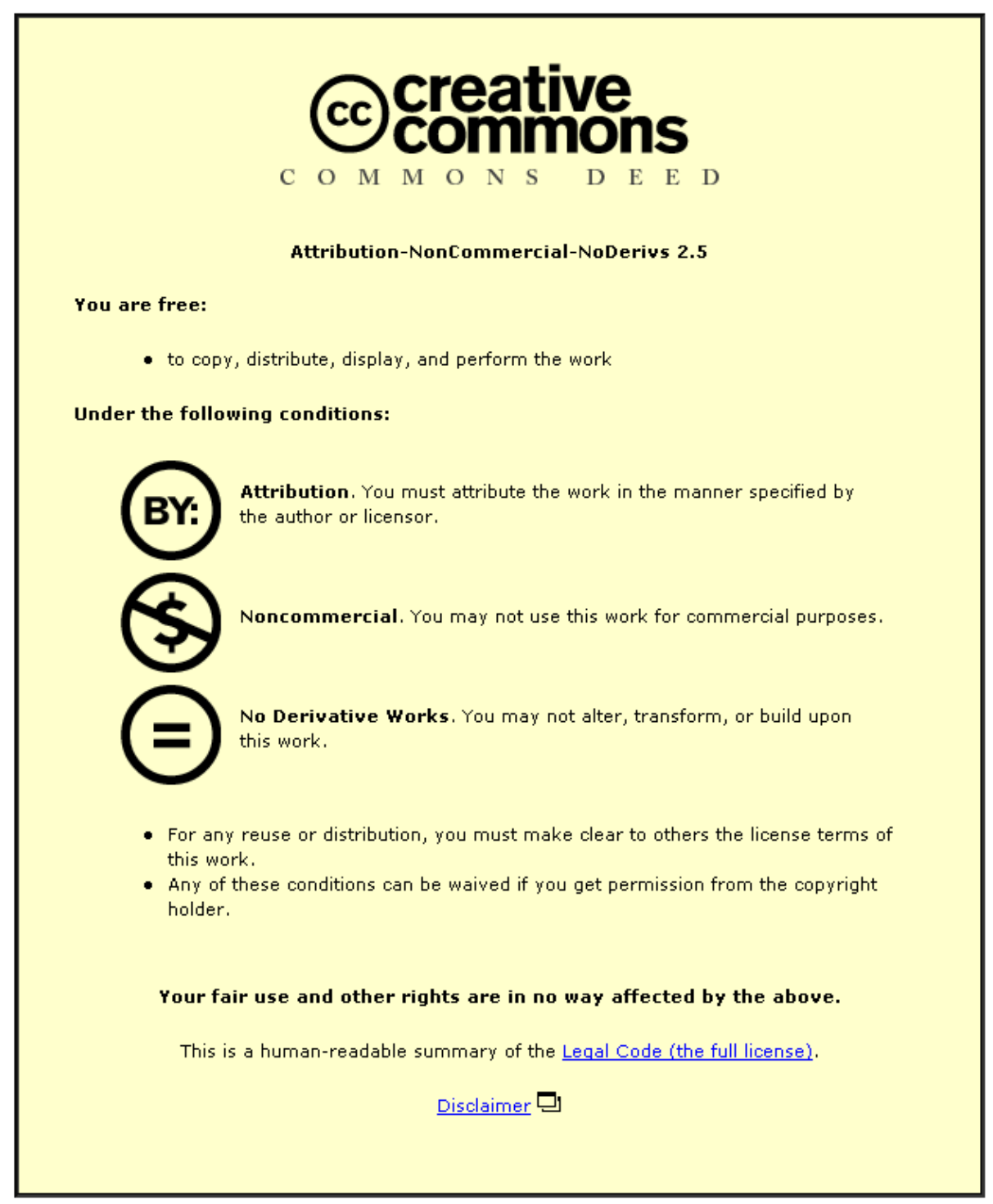

For the full text of this licence, please go to: http://creativecommons.org/licenses/by-nc-nd/2.5/ 


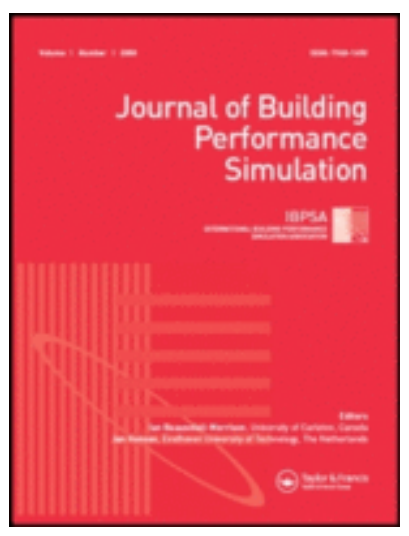

\section{Low Energy Refurbishment Strategies for Health Buildings}

\begin{tabular}{|r|l|}
\hline Journal: & Journal of Building Performance Simulation \\
\hline Manuscript ID: & TBPS-2009-0021.R1 \\
\hline Manuscript Type: & Original Article \\
\hline Keywords: & $\begin{array}{l}\text { hospital, refurbishment, natural ventilation, passive cooling, solar } \\
\text { gain, simulation }\end{array}$ \\
\hline
\end{tabular}

\section{S ScholaroNE \\ Manuscript Central}




\title{
Low Energy Refurbishment Strategies for Health Buildings
}

\author{
(Received 3 April 2009; final version received day month 2009)
}

\begin{abstract}
Public health buildings contribute significantly to UK carbon emissions. New build initiatives have received more attention than the considerable opportunities to reduce carbon emissions within the retained health estate. The research reported here has considered the environmental performance of a typical medium rise, medium depth, concrete-framed, late 1960s acute hospital following low energy environmental design interventions. The interventions are made to optimise daylighting and natural ventilation/cooling whilst reducing overheating caused by summertime solar gains. Three options are investigated: advanced natural ventilation using plena and exhaust stacks; fan-assisted natural ventilation, in which fans are used in the exhaust stacks; and mechanical ventilation/cooling with heat recovery. Computer simulations have been carried out to predict the influence on thermal performance (overheating risk) and energy consumption of each of these options on the original design. For each case, current weather data, and future weather data for years 2020, 2050 and 2080, have been used.
\end{abstract}

Keywords: hospital; refurbishment; natural ventilation; passive cooling; solar gain; simulation

\section{Introduction}

The Consultation Draft of the National Health Services (NHS) Carbon Reduction

Strategy, drafted by the NHS Sustainable Development Unit (2008. pp.3-7) reveals that the "NHS in England is responsible for more than 18 million tonnes of carbon dioxide per annum". This is about $3 \%$ of UK carbon dioxide emissions and $30 \%$ of public sector emissions, and costs approximately $£ 429$ million annually on heating and lighting alone. Mandatory climate change-related targets were introduced in 2001 by the Department of Health (Department of Health) for the NHS, as part of the response to the 2000 Climate Change Programme introduced in March 2000 wherein each Government department was required to identify targets to reduce carbon dioxide emissions (NHS Estate, 2004). As explained in Health Technical Memorandum 07-02 $\mathrm{EnCO}_{2}$ de (Department of Health, 2005.p. 3), NHS organizations in England are currently required to deliver efficiency savings of $15 \%$ energy or $0.15 \mathrm{MtC}$ (million tonnes carbon) between March 2000 and March 2010. They are also committed to achieving a target of $35-55 \mathrm{GJ} / 100 \mathrm{~m}^{3}$ energy performance for all new capital development and $55-65 \mathrm{GJ} / 100 \mathrm{~m}^{3}$ for the refurbishment of existing facilities. The DH has reliable information (Estates Returns Information 
Collection (ERIC), 2008a), on the energy performance of the Retained Estate recording a range of $70-125 \mathrm{GJ} / 100 \mathrm{~m}^{3}$, well above the current DH target. In 2004/05, the reported energy performance of the majority of NHS Trust acute hospitals in England was in the range of 44.8 to $98.0 \mathrm{GJ} / 100 \mathrm{~m}^{3}$. The report "Statistics on energy performance and carbon and CO2 emissions" (Department of Health, 2006) estimates the lower and upper ranges of acute hospital energy consumption within the NHS Retained Estate in England in 2004/05 (Table 1). There is therefore an imperative to reduce energy use and, apparently, scope to do so. However, the Director of Estates and Facilities Management at the DH has commented 'no one knows how to achieve these targets in a health context, or if it is possible without compromising patient safety and well-being'. ${ }^{1}$

The NHS Trusts in England will now be required to further reduce their carbon footprint (NHS Sustainability Development Unit, 2008). It is proposed that "by 2009, all NHS organizations should set out ambitions, milestones and actions for carbon reduction across the areas of building energy use, travel, procurement, and waste in a Board approved Carbon Management Strategy". An ambitious carbon reduction challenge set by this proposed strategy requires all new NHS facilities to be low carbon by 2015 , and to meet the Government ambition for zero carbon, non- domestic buildings by 2018 (Ibid. pp.13, 16).

Around $44 \%$ of the energy used in a typical hospital is for air and space heating (Department of Health, 2005). Another 13\% is consumed by fans. Thus superficial consideration suggests that climatic warming may reduce energy consumption. However, very little of the Retained Estate is air-conditioned, and in the poorly insulated, often over-glazed stock, an increased incidence of summer time overheating is a very real risk.

\footnotetext{
${ }^{1}$ Comment to Healthcare Sector Board, (01/05/2008) Modern Built Environment (MBE) Knowledge Transfer Network (KTN)
} 
Such overheating can have serious consequences as healthcare buildings have a relatively high number of very heat-sensitive occupants unable to take adaptive action to keep cool. The Chief Medical Officer is clear in the Department of Health 2008 Heatwave Plan (Department of Health, 2008b): 'During relatively mild heatwaves, excess death rates are significantly, but avoidably, higher in this country [UK]'. The risk of future overheating is exacerbated by the increasing use of electrical equipment as a key component of care programmes, a trend that is likely to continue. Any move to use air-conditioning to combat these risks will add to the already high use of energy.

Although the NHS is attempting to meet its energy-related targets, recent evidence of NHS energy performance suggests that NHS organisations in "both England and Wales are struggling to meet their energy-reduction targets and the 15 per cent emissionsreduction target is unlikely to be met" (The NHS Confederation, 2007, p. 9). Statistics on NHS energy performance in England between 1999 and 2005 indicate that while energy is being used more efficiently within the NHS sector over this period, energy consumption has increased by 7 per cent to 44.8 million GJ (Department of Health, 2006). Over the same five year period, total carbon and $\mathrm{CO} 2$ emissions attributed to NHS Trusts in England also increased by $11 \%$. The NHS had 14,040 sites in mid 2008 of which $21.7 \%$ of the buildings in use were constructed pre-1948, and 24.5\% were built between 1948 and 1974. The 'SHINE' website (2009) reveals only 12 exemplar low energy NHS projects of which three are refurbishments. It has been suggested that, as a major contribution to achieving zero carbon regulated energy and occupant energy use by 2016 , "the refurbishment of the existing building stock is a further opportunity to improve the environmental sustainability of NHS buildings that should not be missed" (Department of Health, 2008c). 
Computer simulation programs are now used extensively to predict energy and thermal performance of building designs, especially in innovative designs for which the impact of design strategies such as solar shading, exposed thermal mass and night ventilation are difficult to quantify without the use of modelling. Previous applications of simulation to healthcare building design include the work of Narayan et al. (2006) who used Radiance and DOE2 to assess visual comfort, daylight penetration and the thermal comfort response to several design strategies for two healthcare projects. Miguet and Groleau (2002) used a newly developed simulation tool to investigate the daylight performance of a hospital near Paris. Their example illustrates the value of daylight modelling in providing "essential information to the architect". Simulation has also been used to model the performance of individual spaces within a healthcare facility. For example, Melhado et al. (2005) used dynamic thermal simulation to compare the energy and thermal performance of three operating room layouts.

The work reported in this paper was part of a National Institute for Health Research (NIHR) funded project which investigated the opportunities for reducing NHS energy consumption apparently available in the refurbishment of the existing stock. This paper focuses on Northwick Park Hospital in west London, a representative concrete frame, lightweight clad, medium rise, medium depth hospital. The building lies within, but towards the perimeter of, the London heat island (Watkins et al, 2002) putting it at greater risk of overheating during summer periods due to the reduced cooling potential of night time ventilation. This paper shows how computer simulation was used to assess the relative impact on thermal, energy and daylight performance of three proposed refurbishment options. 


\section{The Maternity Wing at Northwick Park Hospital}

Most (97\%) of the buildings constructed on the Northwick Park site were constructed between 1965 and $1974^{2}$. Data collected from all healthcare trusts in England show that $14 \%$ of the (whole) estate was constructed during the same period as Northwick Park (between $1965-1974)^{2}$. Northwick Park Hospital, designed in 1962/63 is therefore considered typical of highly glazed, concrete constructions of that era (figures 1 and 2). The concrete mullions visible in figure 2 , were intended to control glare at critical points in the interior of the building by clustering them at some points more closely than at others but this was abandoned in favour of representing a vertical gathering of structural forces, floor by floor. The impact of these external concrete fins on solar gains is analysed in the paper. A band of clerestory windows, some opening, sit above sliding sash windows. Below the cill line are aluminium-faced spandrel panels. Over half the elevation is clear single glazing.

The work reported in this paper has focused on the maternity wing, located in the north-west corner of the site. The environmental characteristics of the maternity wing, in its as-built condition, are summarised in figures 3 and 4 . The summer condition (Figure 3) shows the building to be subject to direct solar gain through single glazing, and by conduction through the fabric, the concrete is largely un-insulated. The potential to exploit the structural mass to achieve night ventilation cooling is reduced by the lack of a controlled ventilation strategy. Lightweight ceilings shield the slabs from occupants. Internal occupant and equipment gains are considerably higher than envisaged 40 years ago and lighting fixtures and hot water pipes contribute to internal gains.

The winter condition (Figure 4) reveals the likelihood of prodigious heat losses due to lack of insulation and infiltration losses through the ill-fitting glazing and cladding. Winter solar gains and glare are apparent on winter days behind south, west and east

${ }^{2}$ private correspondence S. Wright, Estates and Facilities Division, Department of Health 
elevations. Internal blinds are in widespread use, reducing daylighting effectiveness and single glazing induces cold downdraughts.

\section{As-built Performance}

\subsection{Daylight and Solar Modelling}

An advanced simulation package TownScope (2004) was used to simulate the solar gain distribution for a simple flat facade model and a facade model which included the contribution of the existing external concrete framing. The development of this tool by the University of Liege under the sponsorship of the European Commission was part of a research programme on urban renewable (Azar, 2004; Teller and Azar, 2001). TownScope is currently a well established software package in the research community and has already been used for many projects (e.g. Cremasco and Dupagne,1999; Teller, 2002; Littlefair et al 2000, Al-Maiyah and Elkadi, 2007). The current version (TownScope v.3.0.1) can predict the three energy components of solar radiation as well as thermal comfort for any geographic location and sky conditions. In a recent study by Elkadi and Al-Maiyah (2007) the tool was also used to assess the impact of the change in the reflected energy of solar radiation on the visual experience of historic areas in both Edinburgh and Cairo. Validation exercises carried out using TownScope demonstrate its reliability in solar radiation assessment (Al-Maiyah, 2006).

In this study, to perform this first phase of simulation, appropriate photometric properties were assigned to the developed model(s) and detailed monthly climatic data for the cloud cover, diffused and direct solar energy and atmosphere turbidity. The threedimensional models predicted the distribution of the direct, diffuse, reflected, and total solar radiation for all facades in mid June and December (e.g. Figure 5 shows results for the distribution of total solar radiation for the west facing elevation). The simple model 
simulations show the full exposure of the largely glazed elevations. The projecting concrete frame and slabs form an egg-crate shading system, but the model reveals the interval between verticals and horizontals to be too great to protect the elevations adequately. For example, total incident energy at mid June on the west elevation, is reduced from $2,890 \mathrm{Wh} / \mathrm{m}^{2}$ (simple model) to approximately $2,000 \mathrm{Wh} / \mathrm{m}^{2}$ (as-built). The west-facing rooms are affected by reflected solar energy (approximately $320 \mathrm{Wh} / \mathrm{m}^{2}$ ) in mid June due to the projecting wings either side. This is a function of the $\mathrm{H}$ plan geometry and is particularly significant on the first floor.

In temperate regions such as the UK, where overcast days occur for a significant proportion of the year, it is important to investigate the overcast sky luminance (Danny et al, 2004). However, in summer 2006 the UK has experienced noticeable changes in its climate with 12 th July 06 being recorded the hottest day ever recorded in the UK and autumn 2006 was the hottest since 1659 (The Guardian, 2006). With the effects of climate change taking place, which is already having an influence on the global average surface temperature (IPCC, 2007), it was therefore appropriate to assess the daylighting performance of the existing envelope under clear sky as well as overcast conditions. Daylighting levels are therefore predicted under three sky conditions (CIE Sunny Sky, CIE Clear Sky without Sun and CIE Overcast Sky), for mid March, mid June and mid September at $9 \mathrm{am}, 12 \mathrm{pm}$ and $3 \mathrm{pm}$ on each day. The daylighting performance behind the existing façade configuration for a south facing four-bed ward in March, June and September was investigated using a three-dimensional CAD model exported to the ADELINE (v.3) (Advanced Daylighting and Electric Lighting Integrated New Environment) simulation tool (2009). Selected results illustrating the daylighting performance are shown in Figure 6. Full results can be found in Table 2. In the case of the existing façade, the analysis shows that under the three sky conditions examined, south 
facing wards tend to receive daylight levels significantly higher than the recommended illuminance levels (100 to 150 lux in bedded areas, CIBSE, 1989 and 100 lux general lighting in patient wards, CEN Standard, 2006). The analysis reveals that the building is highly over glazed, attracting prodigious solar gains in summer contributing to overheating. The result for the CIE Clear sky case, mid March at 3pm reveals illuminance levels of the order of 11,000 lux immediately behind the glazed elevation, whilst at the back of a four-bed ward of the order of 1,200 Lux, well above the recommended illuminance levels (CIBSE 1989 and CEN Standard 2006). This level of contrast is likely to induce the perception of gloominess within the ward and therefore the near-permanent use of artificial lighting which was observed by the authors on site visits.

\subsection{Dynamic Thermal Simulation}

The IES VE software (version 5.9.0, 2008) was used to carry out dynamic thermal modelling. Within IES VE, ApacheSim coupled with a network airflow model was used for thermal simulation. This is an established tool for analysing the dynamic behaviour of single spaces and whole buildings including heating demands, cooling loads, casual and solar gains. ApacheSim provides comprehensive predictions of indoor air temperatures, dry resultant temperatures, $\mathrm{CO} 2$ concentrations and ventilation rates. The model used for analysis comprised 30 spaces selected to represent the wide range of space types and conditions present in the maternity wing. These were arranged to form a block of largely thermally disconnected spaces distributed over four storeys. The locations of the rooms modelled are shown in Figures 7a, 7b, 7c and 7d. The constructions used are given in Table 3 and the heat gains assumed in the model, taken from the DH Activity Database (2008d), are given in Table 3. Infiltration levels of $0.45 \mathrm{ac} / \mathrm{h}$ were assumed.

Three types of room were modelled for this case: (i) those where mechanical ventilation is used at all times because rooms are in the core of the building with no 
access to perimeter ventilation openings or windows; (ii) those on the perimeter of the building where single-sided ventilation is used in winter and mechanical ventilation in summer; and (iii) those with high heat gains where mechanical ventilation and cooling is used at all times. Where cooling is used, the cooling set point used was $25.5^{\circ} \mathrm{C}$. Where mechanical ventilation is used, a flow rate of $4 \mathrm{ach}^{-1}$ was modelled. The ventilation schemes used are summarised in Table 5.

Each version of the computer model was simulated using the current CIBSE (2005) Test Reference Year (TRY) data for London. The simulations were repeated using future weather data synthesised using the morphing algorithm developed by Hacker et al (2005). This uses past weather data to produce TRYs for 2020, 2050 and 2080. The effects of this morphing algorithm are shown in Figure 8.

Table 6 shows the predicted number of occupied hours when the air temperature exceeds $28^{\circ} \mathrm{C}$, for each space modelled using the current building construction. HTM0301 (2007) states that the air temperature in patient areas should not exceed $28^{\circ} \mathrm{C}$ for more than 50 occupied hours per year. Figures shown in red indicate the number of hours during which it is predicted that this will be exceeded.

When exposed to the 2005 climate the as-built building appears to be relatively resilient. However, by 2020 the simulations predicted the majority of occupied spaces will exceed 50 hours above $28^{\circ} \mathrm{C}$. By 2050 almost all spaces are seriously overheating and by 2080 all are. The results therefore suggest that the as-built building has no short or medium term resilience.

\section{Refurbishment strategy}

Figure 9 depicts the existing elevation overclad. The existing glazing is removed and a new deep elevation used which incorporates significant glazing to upper floors. Solar shading is provided to the new windows by deep, canted reveals. A network of 
interlocking air supply and exhaust ducts is threaded between these glazed element. Figure 9 also shows a lateral section through the depth of the proposed new façade revealing, in passive mode, the pattern of fresh air supply ducts, receiving air from intakes configured to sustain a positive pressure (as employed by the authors in the refurbishment of the Poole Arts Centre (XXX), and the exhaust ducts above connecting to a windresisting termination (a design also employed by the authors at Poole Arts Centre and Contact Theatre (Ibid). A fan is indicated at the base of the termination operated by a flow sensor to counteract the periodic tendency to downdraught. Intakes into each room are shown at low level and exhausts at high level which exploits the upward buoyancy forces in the space (Figure 10).

The refurbishment in Figure 9 indicates the availability of a mechanical mode, potentially required in the south of England and certainly within the London heat island (Watkins et al, 2002). The stack termination is sealed by dampers and exhaust air is drawn out of the collection plenum into a return duct behind the parapet connecting to a centralised air-handling unit, in which heat is received, and cooling provided. Supply air is ducted to the base of the supply stacks along the elevation.

This hybrid arrangement theoretically enables the building, or separate compartments, to cycle between natural and mechanical modes. The controls will be more complex than a single mode system but energy savings will be maximised, and the building will acquire greater resilience to the warming climate.

\subsection{Daylight and Solar Modelling of the refurbishment strategy}

Figure 11 shows the effect on solar gain on the west façade in mid-June and mid-

December due to the imposition of the double façade. Not all glazing is shielded, particularly in December, but peak incident total solar gain of approximately 1,700 $\mathrm{Wh} / \mathrm{m} 2$ in a limited area of glazing is predicted in mid-June, a considerable reduction on 
the existing gains (approximately 32\% reduction relative to the existing gain of 2,500

$\mathrm{Wh} / \mathrm{m} 2)$. The distribution of daylighting across a south facing ward is also improved (c.f. figures 6 and 12, and tables 2 and 7). For example, for the CIE clear sky mid March case without sun, a maximum total illuminance of 7,400 lux is predicted at the window and 340 lux at the innermost corner of the ward. The modelling of the CIE sunny sky in June reveals a significant difference in terms of daylight distribution when compared with the existing case. Despite the usefulness of this shading strategy in reducing the undesired solar gain in summer, it is evident from the simulation modelling that the imposition of the double facade has also led to about $29 \%$ - 36\% reduction of useful winter gain (e.g. on a large area of glazing of the west elevation, total incident energy at mid December is reduced from $276 \mathrm{Wh} / \mathrm{m}^{2}$ (as-built) to around $195-171 \mathrm{Wh} / \mathrm{m}^{2}$ (refurbishment scheme)). This is a design compromise due to the imposition of the ventilation stacks.

\subsection{Thermal Performance of the refurbishment strategy in various operating modes} Table 8 summarises the constructions used in modelling the refurbishment configuration and Table 9 shows the heat gain assumptions based on data from the DH Activity Database (2008d). A reduced infiltration of $0.25 \mathrm{ach}^{-1}$ was assumed.

The proposed refurbishment scheme considers the following three modes of operation for ventilation and cooling. The rooms to which these changes were applied are identified by the shading in Table 10 .

The first mode of operation (case 2 in Table 10), referred to as 'Advanced Natural Ventilation' (ANV), uses natural buoyancy forces to draw in ambient air through a shared low-level plenum to the spaces to be ventilated and to drive stale warm air through highlevel terminals via individual exhaust stacks built into the façade of the building. No fans or cooling are used in the refurbished zone for this mode. 
The second mode of operation (case 3 in Table 10), referred to as 'Fan-Assisted Natural Ventilation' (FANV), uses fans to draw air out through the high-level terminals which enables air to flow in at low-level naturally.

The third mode of operation (case 4 in Table 10), referred to as 'Shared Mechanical Ventilation with Shared Mechanical Cooling' M1(V+C) uses mechanical ventilation equipment to supply conditioned air to the shared low-level plenum and extract warm stale air from the high-level shared exhaust plenum. This system includes a heat recovery system. The heating and cooling set points, which are based on the air temperature in the inlet plenum, are $20^{\circ} \mathrm{C}$ and $26^{\circ} \mathrm{C}$ respectively.

In all three refurbishment cases, the opening sizes are determined by the air temperature and $\mathrm{CO} 2$ concentration in the room being served. The opening size is varied linearly from fully closed to fully open as the air temperature rises from $23^{\circ} \mathrm{C}$ to $25^{\circ} \mathrm{C}$ or the $\mathrm{CO} 2$ concentration rises from $800 \mathrm{ppm}$ to $2000 \mathrm{ppm}$. For the FANV and M1(V+C) modes a variable air volume system was modelled which used the temperature in the exhaust plenum as the parameter for determining the required flow rate.

Table 11 summarises results for the predominantly ANV operation of the proposal (case 2). All the ANV spaces are robust to the $28^{\circ} \mathrm{C}$ limit in 2020 , most maintain 100 hours or less by 2050 , but half exceed 50 hours, and by 2080 all overheat for considerable periods. The addition of fan assistance (Table 12) begins to increase resilience, especially on the third floor where buoyancy forces are smallest, so that by 2050 all ANV spaces remain below $28^{\circ} \mathrm{C}$ for under 100 hours. For case 4 (hybrid mechanical/natural ventilation strategy) all spaces were controlled to remain below $28^{\circ} \mathrm{C}$.

Figures 13 and 14 show the predicted annual energy consumption for each variation of the computer model using current CIBSE weather data (2005) and future weather data for the years 2020, 2050 and 2080. In general there is a reduction in the 
heating energy (gas) consumption as the construction is improved due to better insulation and improved air-tightness. However, these savings may be over-predicted due to simplifications in the thermal model whereby distribution heat losses were ignored. Overall, there is a saving of approximately $22 \%$ between the as-built case and case 4 (the hybrid case which was able to deliver thermal comfort for all future weather data). The result is an energy consumption prediction which is below current DH targets. Figure 14 shows the energy consumption by usage. Although the equipment energy usage was assumed to remain constant, it is likely that equipment will become more efficient in the future and that this will yield further reductions in total energy consumption. The amount of cooling increases from the current weather data through to 2080, although the increase for case $1(300 \%)$ is greater than case $4(270 \%)$ due to the hybrid nature of the ventilation and cooling system and the solar protection afforded by the refurbishment design. The corresponding carbon emissions savings between case 1 and case 4 are approximately $10 \%$ (Figure 15). This is less than the energy savings due to the higher carbon emissions associated with electrical energy use relative to gas usage.

\section{Conclusions}

The Northwick Park Maternity Wing is not atypical of medium rise buildings of the relatively recent past, comprising a heavy concrete frame and severely compromised by an almost all glazed, very lightweight envelope. A holistic approach to refurbishment is the most fruitful in which excessive solar gain and highly non-uniform daylighting can be corrected whilst the performance of the envelope is enhanced to reduce heat losses and gains. Once a level of airtightness is achieved, a more controlled ventilation strategy can be developed and the inherent structural mass employed to assist passive cooling. Natural buoyancy forces will drive airflows most of the time but it would be judicious to provide 
fan assistance to ensure consistency of flows not least to mitigate airborne spread of infection.

The modelling has shown that the building as currently constructed and operated is likely to suffer over-heating in about one-in-five of the spaces modelled. In future years this problem is likely to increase significantly unless changes to the ventilation and cooling strategy are made.

Use of an Advanced Natural Ventilation system in which buoyancy forces are used to draw in fresh air through a shared low-level plenum with cross venting to exhaust stacks, shows a marked improvement in the thermal performance, to the extent that the system is likely to deliver acceptable performance for the 2020 climate data. Fan-assisted natural ventilation improves on this further but full mechanical cooling is required in order to eliminate over-heating completely.

Energy consumption figures for the refurbishment cases show an improvement of about $22 \%$ compared with the current building construction with very considerably improved comfort. In general, heating energy consumption reduces as the climate warms and cooling energy increases. It is likely that the energy consumed by equipment may also decrease in time as more energy-efficient systems become available. However, it was not possible to accurately model this effect in this work. There is an urgent need for the collection and analysis of field data in this regard.

The modelling work has shown how low energy building design principles which consider the fabric and form of the building can be used in refurbishment projects to deliver significant savings in energy in line with current DH targets. Further work could be carried out to improve the assumptions made in the dynamic thermal simulation models, although the predictions so far are encouraging. This work has also highlighted to 
value of recently generated future TRY weather data for use in 'future proofing' building designs.

\section{References}

ADELINE 3, Advanced Daylighting and Electric Lighting Integrated New Environment, International Energy Agency, Solar Heating and Cooling Program- Task 29: Daylight in Buildings, http://www.ecbcs.org/annexes/annex29.htm.

Al-Maiyah , S,. (2006) Daylighting and Sustainability of Place in Cultural Built Heritage Contexts, Unpolished PhD thesis, School of the Built Environment, Faculty of Engineering, University of Ulster.

Al-Maiyah, S. and Elkadi, H. (2007) The role of Daylight in Preserving Identities in Heritage Context, Journal of Renewable \& Sustainable Energy Reviews, 11(7), pp.1544-1557.

Azar, S. (2004) TownScopeIII - user's manual.

Chartered Institute of Building Services Engineers (CIBSE) (1989) Lighting Guide: Hospitals and Health Care Buildings, CIBSE, London.

Cremasco, V. and Dupagne, A. (1999) Case Study: Radiation- Solar Comfort- Early analysis in High Density Urban Context [online]. Available at: $<$ http://www.cardiff.ac.uk/archi/programmes/cost8/case/assessment/Belgiumradiationsolar.pdf $>$ [7 September 2006].

Danny, H.W. Li, Chris C. S. Lau and Joseph C. Lam (2004) Overcast sky conditions and luminance distribution in Hong Kong, Building and Environment, 39 (1), pp. 101108.

Department of Health 2005 Health Technical Memorandum 07-02: EnCO2de-making energy work in healthcare, London: The Stationary Office, p.4, Figure 3.

Department of Health, Estate and Facilities Division (2006) Statistics on energy performance and carbon and CO2 emissions, NHS England, 1999/00 to 2004/05 (with prediction to 2009/10), London: The Stationary Office.

Department of Health 2008a Estate Returns Information Collection (ERIC), (available from http://www.dh.gov.uk).

Department of Health 2008b Heatwave plan for England: Protecting health and reducing harm from extreme heat and heatwaves, NHS Publications, p.3.

Department of Health, 2007, Heating and ventilation systems. Health Technical Memorandum HTM03-01: Specialised ventilation for healthcare premises. The Stationary Office, London.

Department of Health, 2008c, Health Technical Memorandum 07-07: Sustainable Health and Social Care Buildings, consultation document.

Department of Health, 2008d, Activity Database, version 19.0, http://adb.dh.gov.uk.

Elkadi , H. and Al-Maiyah, S. and (2007) Daylight for Strategic Intervention in Historic Towns: The Case of Edinburgh and Cairo. Journal of Urban Technology, 14 (3), pp.83-102.

European Committee for Standardization 2006 prEN 15251 final draft: indoor environmental input parameters for design and assessment of energy performance of buildings addressing indoor air quality, thermal environment, lighting and acoustics, Brussels, CEN.

Guardian, The (2006), This year will be Britain's warmest since records began, say scientists, available online at: 
http://www.guardian.co.uk/world/2006/dec/14/weather.topstories3, accessed 3 April 2009.

Hacker J.N., Holmes M.J., Belcher S.E. and Davies G. Climate Change and the Indoor Environment: impacts and adaptation (CIBSE TM 36) (2005), Chartered Institution of Building Services Engineers, London.

IES VE, version 5.9.0, http://www.iesve.com.

Littlefair, P., Santamouris, M., Alvarez, S., Dupagne, A., Hall, D., Teller, J., Coronel, J.F., Papanikolaou, N. (2000) Environmental site layout planning: solar gain, microclimate and passive cooling in urban areas. London: Construction Research Communications.

Melhado M.A., Beyer P.O., Hensen J.M. and Siqueira L.F.G. The thermal comfort, the indoor environmental control and the energy consumption in three types of operating rooms, Building Simulation Conference, Montreal, Canada, 15-18 August, 2005.

Miguet F and Groleau D. A daylight simulation tool for urban and architectural spaces application to transmitted direct and diffuse light through glazing, Building and Environment, 37, pp833-843, 2002.

Narayan S., Lavedrine I. and McClintock M. Simulation strategies for healthcare design to achieve comfort and optimize building energy use, SimBuild Conference, Massachusetts Institute of Technology, 2-4 August, 2006.

IPCC (2007) Climate Change 2007: Synthesis Report. An Assessment of the Intergovernmental Panel on Climate Change, Valencia, pp. 30-37.

NHS Estates 2004 Carbon/ energy management in healthcare. Best practice advice for the NHS in England on meeting the mandatory carbon/ energy targets- March 2000 March 2010, London, The Stationary Office.

NHS Confederation 2007 Taking the temperature: towards an NHS response to global warming, London, NHS Confederation Publications.

NHS Sustainability Development Unit 2008 Saving Carbon, Improving Health: A Draft Reduction Strategy for the NHS in England- a consultation document, (available at: http://www.sdu.nhs.uk/get_involved/carbon_reduction_feedback_intro.php), accessed 5 April 2009.

SHINE The Learning Network For Sustainable Healthcare Building, available at: http://www.shine-network.org.uk, accessed 3 April 2009.

XXX 2005 Design guidance for naturally ventilated theatres, Building Service Engineers, XXX.

Teller, J. and Azar, S. (2001) TOWNSCOPE II- a computer system to support solar access decision-making, Solar Energy, 70 (3), 187-200.

Teller,J (2002) SUIT :Sustainable development of Urban historical areas through an active Integration within Towns (Task 2.3- Morphological Indicators System) [online]. Available at: <http://www.lema.ulg.ac.be/research/suit/Reports/Members/SUIT2.3_Report.pdf\# search $=\% 22$ Task\%202.3-Morphological\%20indicators\%20system\%22>[7

September 2006].

TownScope version 3.0.1 simulation package, (available from http://www.townscope.com), accessed 3 April 2009.

Watkins, R., Palmer, J., Kolokotroni, M. and Littlefair, P. (2002) The balance of the annual heating and cooling demand within the London urban heat island, Building Service Engineering Research Technology, 23 (4), pp. 207-213. 
Table 1. Estimated acute hospital energy consumption within the NHS retained estate (Department of Health, 2006)

\begin{tabular}{|c|c|c|}
\hline Hospital Type & Location & $\begin{array}{c}\text { Energy Consumption } \\
\left(\mathrm{G} \mathbf{J} / 100 \mathrm{~m}^{\mathbf{3}}\right)\end{array}$ \\
\hline \multirow[t]{2}{*}{ Small Acute } & within London & $55.98-84.29$ \\
\hline & outside London & $61.06-75.08$ \\
\hline \multirow[t]{2}{*}{ Medium Acute } & within London & $54.47-66.02$ \\
\hline & outside London & $61.36-74.33$ \\
\hline \multirow[t]{2}{*}{ Large Acute } & outside London & $62.92-80.26$ \\
\hline & within London & $65.95-79.77$ \\
\hline \multirow[t]{2}{*}{ Acute Teaching } & outside London & $56.90-81.18$ \\
\hline & within London & $77.99-98.02$ \\
\hline Acute specialist & & $54.84-66.02$ \\
\hline
\end{tabular}


Table 2. Daylight Analysis of as-built scheme (south facing room)

\begin{tabular}{|c|c|c|c|c|c|}
\hline 1 & \multicolumn{5}{|c|}{ Sky model: CIE Clear Sky with Sun } \\
\hline & & & \multicolumn{3}{|c|}{ Daylight distribution on the examined bed surface [klux] } \\
\hline \multicolumn{3}{|c|}{ Simulation date/ time } & $\begin{array}{c}\text { Max daylight illuminance } \\
\text { (direct }+ \text { diffuse })\end{array}$ & $\begin{array}{c}\text { Min daylight illuminance } \\
\text { (direct }+ \text { diffuse })\end{array}$ & $\begin{array}{c}\text { Mean daylight illuminance } \\
\text { (direct }+ \text { diffuse })\end{array}$ \\
\hline \multicolumn{2}{|l|}{ March } & 9:00 AM & 32.91 & 1.45 & 9.02 \\
\hline \multicolumn{2}{|l|}{ March } & 12:00 PM & 53.47 & 3.02 & 21.88 \\
\hline \multicolumn{2}{|l|}{ March } & $3: 00 \mathrm{PM}$ & 53.47 & 3.02 & 21.88 \\
\hline \multicolumn{2}{|l|}{ June } & 9:00 AM & 34.74 & 1.69 & 6.1 \\
\hline \multicolumn{2}{|l|}{ June } & 12:00 PM & 63.27 & 2.57 & 13.84 \\
\hline \multicolumn{2}{|l|}{ June } & $3: 00 \mathrm{PM}$ & 35.74 & 1.64 & 6.11 \\
\hline \multicolumn{2}{|l|}{ September } & 9:00 AM & 34.78 & 1.75 & 9.33 \\
\hline \multicolumn{2}{|l|}{ September } & 12:00 PM & 53.47 & 3.28 & 18.78 \\
\hline \multicolumn{2}{|l|}{ September } & $3: 00 \mathrm{PM}$ & 33.4 & 1.7 & 8.95 \\
\hline \multirow[t]{2}{*}{2} & \multicolumn{5}{|c|}{ Sky model: CIE Clear Sky without Sun } \\
\hline & & & $\begin{array}{l}\text { Max daylight illuminance } \\
\text { (diffuse) }\end{array}$ & $\begin{array}{c}\text { Min daylight illuminance } \\
\text { (diffuse) }\end{array}$ & $\begin{array}{c}\text { Mean daylight illuminance } \\
\text { (diffuse) }\end{array}$ \\
\hline \multicolumn{2}{|l|}{ March } & 9:00 AM & 7.65 & 0.75 & 2.67 \\
\hline \multicolumn{2}{|l|}{ March } & 12:00 PM & 11.66 & 1.37 & 4.08 \\
\hline \multicolumn{2}{|l|}{ March } & $3: 00 \mathrm{PM}$ & 8.55 & 0.81 & 2.94 \\
\hline \multicolumn{2}{|l|}{ June } & 9:00 AM & 11.78 & 1.22 & 3.92 \\
\hline \multicolumn{2}{|l|}{ June } & 12:00 PM & 16.56 & 1.7 & 5.4 \\
\hline \multicolumn{2}{|l|}{ June } & $3: 00 \mathrm{PM}$ & 11.93 & 1.23 & 3.97 \\
\hline \multicolumn{2}{|l|}{ September } & 9:00 AM & 12.87 & 1.24 & 4.41 \\
\hline \multicolumn{2}{|l|}{ September } & 12:00 PM & 17.67 & 2.13 & 6.44 \\
\hline \multicolumn{2}{|l|}{ September } & 3:00 PM & 12.56 & 1.21 & 4.3 \\
\hline \multirow[t]{2}{*}{3} & \multicolumn{5}{|c|}{ Sky model: CIE Overcast Sky } \\
\hline & & & $\begin{array}{l}\text { Max daylight illuminance } \\
\text { (diffuse) }\end{array}$ & $\begin{array}{l}\text { Min daylight illuminance } \\
\text { (diffuse) }\end{array}$ & $\begin{array}{l}\text { Mean daylight illuminance } \\
\text { (diffuse) }\end{array}$ \\
\hline March & & 9:00 AM & 2.61 & 0.23 & 0.81 \\
\hline March & & 12:00 PM & 3.93 & 0.34 & 1.22 \\
\hline March & & $3: 00 \mathrm{PM}$ & 2.88 & 0.25 & 0.89 \\
\hline June & & 9:00 AM & 4.72 & 0.41 & 1.47 \\
\hline June & & 12:00 PM & 5.84 & 0.51 & 1.81 \\
\hline June & & $3: 00 \mathrm{PM}$ & 4.77 & 0.41 & 1.48 \\
\hline September & & 9:00 AM & 3.29 & 0.28 & 1.02 \\
\hline September & & $12: 00 \mathrm{PM}$ & 4.42 & 0.38 & 1.38 \\
\hline September & & $3: 00 \mathrm{PM}$ & 3.22 & 0.28 & 1 \\
\hline
\end{tabular}




\begin{tabular}{|c|c|c|}
\hline Element & Construction & U-value $\left(\mathbf{W} / \mathbf{m}^{2} \mathbf{K}\right)$ \\
\hline External Walls & $\begin{array}{l}\text { Cast Concrete } 350 \mathrm{~mm} \\
\text { Plaster } 13 \mathrm{~mm}\end{array}$ & 2.19 \\
\hline External Glazing & Clear Float Glass 4mm & 5.53 \\
\hline Spandrel Panels & $\begin{array}{l}\text { Aluminium } 2 \mathrm{~mm} \\
\text { Plywood } 25 \mathrm{~mm}\end{array}$ & 2.9 \\
\hline Internal Walls & $\begin{array}{l}\text { Plaster } 13 \mathrm{~mm} \\
\text { Concrete Block 105mm } \\
\text { Plaster } 13 \mathrm{~mm}\end{array}$ & 2.04 \\
\hline Internal Floor/Ceiling & $\begin{array}{l}\text { Cast Concrete } 400 \mathrm{~mm} \\
\text { Cavity } 340 \mathrm{~mm} \\
\text { Ceiling Tiles } 10 \mathrm{~mm}\end{array}$ & 1.95 \\
\hline Flat Roof & $\begin{array}{l}\text { Stone Chippings } 10 \mathrm{~mm} \\
\text { Felt/Bitumen Layers } 5 \mathrm{~mm} \\
\text { Cast Concrete } 100 \mathrm{~mm} \\
\text { Cavity } 340 \mathrm{~mm} \\
\text { Ceiling Tiles } 10 \mathrm{~mm}\end{array}$ & 1.63 \\
\hline
\end{tabular}


Table 4 Heat gains used in the as-built dynamic thermal simulation

\begin{tabular}{|l|c|c|c|c|c|c|c|}
\hline \multirow{2}{*}{ Space Name } & \multirow{2}{*}{$\begin{array}{c}\text { Equip } \\
\text { ment }\end{array}$} & \multicolumn{2}{|c|}{ Day-time 08:00 to 20:00 } & \multicolumn{3}{|c|}{ Night-time 20:00 to 08:00 } \\
\cline { 3 - 8 } & $\begin{array}{c}\text { Lighting } \\
\text { (W) }\end{array}$ & $\begin{array}{c}\text { Occupancy } \\
\text { (W) }\end{array}$ & $\begin{array}{c}\text { Density } \\
\left(\mathbf{W} / \mathbf{m}^{2}\right.\end{array}$ & $\begin{array}{c}\text { Lighting } \\
\text { (W) }\end{array}$ & $\begin{array}{c}\text { Occupancy } \\
\text { (W) }\end{array}$ & $\begin{array}{c}\text { Density } \\
\left(\mathbf{W} / \mathbf{m}^{2} \text { ) }\right.\end{array}$ \\
\hline GF Consulting Room 1a & 230 & 273 & 146 & 29 & 0 & 0 & 0 \\
\hline GF Consulting Room 1b & 230 & 273 & 146 & 29 & 0 & 0 & 0 \\
\hline GF Consulting Room 2a & 230 & 184 & 98 & 33 & 0 & 0 & 0 \\
\hline GF Consulting Room 2b & 230 & 184 & 98 & 33 & 0 & 0 & 0 \\
\hline GF Consulting Room 3a & 230 & 167 & 90 & 35 & 0 & 0 & 0 \\
\hline GF Consulting Room 3b & 230 & 167 & 90 & 35 & 0 & 0 & 0 \\
\hline GF Corridor 1a & 0 & 979 & 0 & 12 & 685 & 0 & 8 \\
\hline GF Corridor 1b & 0 & 979 & 0 & 12 & 685 & 0 & 8 \\
\hline GF Toilets 1a & 0 & 367 & 0 & 12 & 257 & 0 & 8 \\
\hline GF Toilets 1b & 0 & 367 & 0 & 12 & 257 & 0 & 8 \\
\hline GF Treatment Room 1a & 700 & 324 & 174 & 44 & 227 & 122 & 39 \\
\hline GF Treatment Room 1b & 700 & 324 & 174 & 44 & 227 & 122 & 39 \\
\hline GF Ultrasound Room 1a & 600 & 210 & 113 & 53 & 147 & 79 & 47 \\
\hline GF Ultrasound Room 1b & 600 & 210 & 113 & 53 & 147 & 79 & 47 \\
\hline FF Four Bed Ward 1a & 400 & 620 & 332 & 26 & 434 & 233 & 21 \\
\hline FF Four Bed Ward 1b & 400 & 620 & 332 & 26 & 434 & 233 & 21 \\
\hline FF Four Bed Ward 2a & 400 & 620 & 332 & 26 & 434 & 233 & 21 \\
\hline FF Four Bed Ward 2b & 400 & 620 & 332 & 26 & 434 & 233 & 21 \\
\hline FF Four Bed Ward 3a & 400 & 620 & 332 & 26 & 434 & 233 & 21 \\
\hline FF Four Bed Ward 3b & 400 & 620 & 332 & 26 & 434 & 233 & 21 \\
\hline SF Delivery Room 1a & 330 & 414 & 222 & 28 & 290 & 155 & 22 \\
\hline SF Delivery Room 1b & 330 & 447 & 239 & 27 & 313 & 168 & 22 \\
\hline SF Four Bed Ward 1a & 400 & 620 & 332 & 26 & 434 & 233 & 21 \\
\hline SF Four Bed Ward 1b & 400 & 620 & 332 & 26 & 434 & 233 & 21 \\
\hline TF Four Bed Ward 1a & 400 & 588 & 315 & 27 & 411 & 220 & 21 \\
\hline TF Four Bed Ward 1b & 400 & 588 & 315 & 27 & 411 & 220 & 21 \\
\hline TF Four Bed Ward 2a & 400 & 588 & 315 & 27 & 411 & 220 & 21 \\
\hline TF Four Bed Ward 2b & 400 & 588 & 315 & 27 & 411 & 220 & 21 \\
\hline FF High Dependency 1a & 5800 & 677 & 363 & 121 & 474 & 254 & 116 \\
\hline FF High Dependency 1b & 5800 & 677 & 363 & 121 & 474 & 254 & 116 \\
\hline
\end{tabular}


Table 5 Ventilation modes used in as-built dynamic thermal simulation model

\begin{tabular}{|c|c|c|}
\hline Room & $\begin{array}{c}\text { May to } \\
\text { Sept }\end{array}$ & $\begin{array}{c}\text { Oct to } \\
\text { April } \\
\end{array}$ \\
\hline GF Consulting Room 1a & MV & SSV \\
\hline GF Consulting Room 1b & MV & SSV \\
\hline FF Four Bed Ward 1a & MV & SSV \\
\hline FF Four Bed Ward 1b & MV & SSV \\
\hline FF Four Bed Ward 2a & MV & SSV \\
\hline FF Four Bed Ward 2b & MV & SSV \\
\hline FF Four Bed Ward 3a & MV & SSV \\
\hline FF Four Bed Ward 3b & MV & SSV \\
\hline SF Delivery Room 1a & MV & MV \\
\hline SF Delivery Room $1 \mathrm{~b}$ & MV & MV \\
\hline SF Four Bed Ward 1a & MV & SSV \\
\hline SF Four Bed Ward 1b & MV & SSV \\
\hline TF Four Bed Ward 1a & MV & SSV \\
\hline TF Four Bed Ward 1b & MV & SSV \\
\hline TF Four Bed Ward 2a & MV & SSV \\
\hline TF Four Bed Ward 2b & MV & SSV \\
\hline GF Consulting Room 2a & MV & SSV \\
\hline GF Consulting Room 2b & MV & SSV \\
\hline GF Consulting Room 3a & MV & SSV \\
\hline GF Consulting Room 3b & MV & SSV \\
\hline GF Corridor 1a & MV & MV \\
\hline GF Corridor $1 \mathrm{~b}$ & MV & MV \\
\hline GF Toilets 1a & MV & MV \\
\hline GF Toilets $1 \mathrm{~b}$ & MV & MV \\
\hline GF Treatment Room 1a & MV & MV \\
\hline GF Treatment Room 1b & MV & MV \\
\hline GF Ultrasound Room 1a & MV & $\mathrm{MV}$ \\
\hline GF Ultrasound Room 1b & MV & MV \\
\hline FF High Dependency 1a & $\mathrm{M} 2(\mathrm{~V}+\mathrm{C})$ & $\mathrm{M} 2(\mathrm{~V}+\mathrm{C})$ \\
\hline FF High Dependency 1b & $\mathrm{M} 2(\mathrm{~V}+\mathrm{C})$ & $\mathrm{M} 2(\mathrm{~V}+\mathrm{C})$ \\
\hline
\end{tabular}

MV mechanical ventilation

SSV single-sided natural ventilation

$\mathrm{M} 2(\mathrm{~V}+\mathrm{C}) \quad$ dedicated mechanical ventilation with mechanical cooling 
Table 6 Thermal performance predictions for the as-built dynamic thermal simulation (without cooling)

\begin{tabular}{|l|cccc|}
\hline & \multicolumn{4}{|c|}{ Hours over 28 $\mathbf{C}$} \\
Room & $\mathbf{2 0 0 5}$ & $\mathbf{2 0 2 0}$ & $\mathbf{2 0 5 0}$ & $\mathbf{2 0 8 0}$ \\
\hline GF Consulting Room 2a & 11 & 48 & $\mathbf{1 8 6}$ & $\mathbf{3 4 4}$ \\
GF Consulting Room 2b & $\mathbf{1 4}$ & $\mathbf{5 4}$ & $\mathbf{1 9 3}$ & $\mathbf{3 4 8}$ \\
GF Consulting Room 3a & $\mathbf{1 5}$ & $\mathbf{4 8}$ & $\mathbf{1 5 5}$ & $\mathbf{2 6 2}$ \\
GF Consulting Room 3b & $\mathbf{1 4}$ & $\mathbf{7 3}$ & $\mathbf{2 1 1}$ & $\mathbf{3 4 4}$ \\
GF Corridor 1a & $\mathbf{0}$ & $\mathbf{0}$ & $\mathbf{1 9}$ & $\mathbf{1 2 0}$ \\
GF Corridor 1b & $\mathbf{0}$ & $\mathbf{0}$ & $\mathbf{1 9}$ & $\mathbf{1 2 0}$ \\
GF Toilets 1a & $\mathbf{0}$ & $\mathbf{0}$ & 23 & $\mathbf{1 2 9}$ \\
GF Toilets 1b & 2 & 3 & 33 & $\mathbf{1 7 8}$ \\
GF Treatment Room 1a & 32 & $\mathbf{6 9}$ & $\mathbf{2 1 2}$ & $\mathbf{5 6 2}$ \\
GF Treatment Room 1b & 32 & $\mathbf{7 2}$ & $\mathbf{2 2 4}$ & $\mathbf{5 8 4}$ \\
GF Ultrasound Room 1a & $\mathbf{5 4}$ & $\mathbf{1 0 7}$ & $\mathbf{3 1 1}$ & $\mathbf{8 1 2}$ \\
GF Ultrasound Room 1b & $\mathbf{5 4}$ & $\mathbf{1 0 7}$ & $\mathbf{3 1 1}$ & $\mathbf{8 1 2}$ \\
\hline GF Consulting Room 1a & $\mathbf{4 8}$ & $\mathbf{1 8 8}$ & $\mathbf{3 5 0}$ & $\mathbf{5 8 8}$ \\
GF Consulting Room 1b & $\mathbf{1 3}$ & $\mathbf{7 9}$ & $\mathbf{2 4 7}$ & $\mathbf{4 2 0}$ \\
FF Four Bed Ward 1a & $\mathbf{1 0 4}$ & $\mathbf{2 9 1}$ & $\mathbf{5 0 2}$ & $\mathbf{9 2 7}$ \\
FF Four Bed Ward 1b & 39 & $\mathbf{1 5 0}$ & $\mathbf{3 1 3}$ & $\mathbf{7 1 0}$ \\
FF Four Bed Ward 2a & $\mathbf{9 3}$ & $\mathbf{2 7 8}$ & $\mathbf{4 8 2}$ & $\mathbf{8 9 0}$ \\
FF Four Bed Ward 2b & 38 & $\mathbf{1 4 1}$ & $\mathbf{3 0 0}$ & $\mathbf{6 8 9}$ \\
FF Four Bed Ward 3a & 37 & $\mathbf{1 0 8}$ & $\mathbf{2 3 5}$ & $\mathbf{4 7 0}$ \\
FF Four Bed Ward 3b & 30 & $\mathbf{8 0}$ & $\mathbf{1 8 1}$ & $\mathbf{3 8 1}$ \\
SF Delivery Room 1a & $\mathbf{5 2}$ & $\mathbf{1 4 9}$ & $\mathbf{3 1 0}$ & $\mathbf{6 8 9}$ \\
SF Delivery Room 1b & $\mathbf{2 4}$ & $\mathbf{7 1}$ & $\mathbf{2 0 7}$ & $\mathbf{5 2 5}$ \\
SF Four Bed Ward 1a & $\mathbf{8 9}$ & $\mathbf{2 7 0}$ & $\mathbf{4 7 1}$ & $\mathbf{8 7 7}$ \\
SF Four Bed Ward 1b & 38 & $\mathbf{1 4 2}$ & $\mathbf{3 0 0}$ & $\mathbf{6 8 5}$ \\
TF Four Bed Ward 1a & 38 & $\mathbf{1 2 0}$ & $\mathbf{2 4 7}$ & $\mathbf{4 7 7}$ \\
TF Four Bed Ward 1b & 38 & $\mathbf{1 1 5}$ & $\mathbf{2 3 1}$ & $\mathbf{4 8 0}$ \\
TF Four Bed Ward 2a & 49 & $\mathbf{1 5 1}$ & $\mathbf{2 5 5}$ & $\mathbf{4 7 2}$ \\
TF Four Bed Ward 2b & $\mathbf{3 2}$ & $\mathbf{9 4}$ & $\mathbf{2 0 2}$ & $\mathbf{4 0 0}$ \\
\hline FF High Dependency 1a & $\mathbf{0}$ & $\mathbf{0}$ & $\mathbf{0}$ & $\mathbf{0}$ \\
FF High Dependency 1b & $\mathbf{0}$ & $\mathbf{0}$ & $\mathbf{0}$ & $\mathbf{0}$ \\
\hline
\end{tabular}


Table 7. Daylight Analysis of refurbishment scheme (south facing room)

\begin{tabular}{|c|c|c|c|c|c|}
\hline & \multicolumn{5}{|c|}{ Sky model: CIE Clear Sky with Sun } \\
\hline & & & \multicolumn{3}{|c|}{ Daylight distribution on the examined bed surface [klux] } \\
\hline \multicolumn{3}{|c|}{ Simulation date/ time } & $\begin{array}{l}\text { Max daylight illuminance } \\
\text { (direct }+ \text { diffuse })\end{array}$ & $\begin{array}{l}\text { Min daylight illuminance } \\
\text { (direct }+ \text { diffuse) }\end{array}$ & $\begin{array}{c}\text { Mean daylight illuminance } \\
\text { (direct }+ \text { diffuse })\end{array}$ \\
\hline \multicolumn{2}{|l|}{ March } & 9:00 AM & 22.68 & 0.48 & 2.2 \\
\hline \multicolumn{2}{|l|}{ March } & 12:00 PM & 50.53 & 1.07 & 7.06 \\
\hline \multicolumn{2}{|l|}{ March } & 3:00 PM & 37.11 & 0.54 & 2.74 \\
\hline \multicolumn{2}{|l|}{ June } & 9:00 AM & 7.15 & 0.49 & 1.54 \\
\hline \multicolumn{2}{|l|}{ June } & 12:00 PM & 57.01 & 0.68 & 3.84 \\
\hline \multicolumn{2}{|l|}{ June } & 3:00 PM & 8.49 & 0.48 & 1.52 \\
\hline \multicolumn{2}{|l|}{ September } & 9:00 AM & 24.02 & 0.62 & 2.3 \\
\hline \multicolumn{2}{|l|}{ September } & 12:00 PM & 48.54 & 1.15 & 7.55 \\
\hline \multicolumn{2}{|l|}{ September } & 3:00 PM & 29.62 & 0.52 & 1.97 \\
\hline \multirow[t]{2}{*}{2} & \multicolumn{5}{|c|}{ Sky model: CIE Clear Sky without Sun } \\
\hline & & & $\begin{array}{l}\text { Max daylight illuminance } \\
\text { (diffuse) }\end{array}$ & $\begin{array}{c}\text { Min daylight illuminance } \\
\text { (diffuse) }\end{array}$ & $\begin{array}{l}\text { Mean daylight illuminance } \\
\text { (diffuse) }\end{array}$ \\
\hline \multicolumn{2}{|l|}{ March } & 9:00 AM & 4.5 & 0.26 & 0.96 \\
\hline \multicolumn{2}{|l|}{ March } & 12:00 PM & 7.39 & 0.34 & 1.49 \\
\hline \multicolumn{2}{|l|}{ March } & 3:00 PM & 6.62 & 0.25 & 0.99 \\
\hline \multicolumn{2}{|l|}{ June } & 9:00 AM & 6.74 & 0.38 & 1.36 \\
\hline \multicolumn{2}{|l|}{ June } & 12:00 PM & 10.38 & 0.47 & 1.83 \\
\hline \multicolumn{2}{|l|}{ June } & 3:00 PM & 8.03 & 0.36 & 1.32 \\
\hline \multicolumn{2}{|l|}{ September } & 9:00 AM & 7.62 & 0.42 & 1.56 \\
\hline \multicolumn{2}{|l|}{ September } & $12: 00 \mathrm{PM}$ & 12.23 & 0.54 & 2.34 \\
\hline \multicolumn{2}{|l|}{ September } & 3:00 PM & 9.72 & 0.38 & 1.44 \\
\hline \multirow[t]{2}{*}{3} & \multicolumn{5}{|c|}{ Sky model: CIE Overcast Sky } \\
\hline & & & $\begin{array}{c}\text { Max daylight illuminance } \\
\text { (diffuse) }\end{array}$ & $\begin{array}{l}\text { Min daylight illuminance } \\
\text { (diffuse) }\end{array}$ & $\begin{array}{c}\text { Mean daylight illuminance } \\
\text { (diffuse) }\end{array}$ \\
\hline March & & 9:00 AM & 1.53 & 0.08 & 0.27 \\
\hline March & & 12:00 PM & 2.31 & 0.11 & 0.4 \\
\hline March & & 3:00 PM & 1.69 & 0.08 & 0.3 \\
\hline June & & 9:00 AM & 2.77 & 0.14 & 0.48 \\
\hline June & & 12:00 PM & 3.43 & 0.17 & 0.6 \\
\hline June & & 3:00 PM & 2.8 & 0.14 & 0.49 \\
\hline September & & 9:00 AM & 1.93 & 0.1 & 0.34 \\
\hline September & & 12:00 PM & 2.61 & 0.13 & 0.45 \\
\hline September & & 3:00 PM & 1.89 & 0.09 & 0.33 \\
\hline
\end{tabular}


Table 8 Constructions used in the refurbishment dynamic thermal simulation

\begin{tabular}{|l|l|c|}
\hline \multicolumn{1}{|c|}{ Element } & \multicolumn{1}{|c|}{ Construction } & U-value (W/m² $\mathbf{K})$ \\
\hline External Walls & $\begin{array}{l}\text { Steel 3mm } \\
\text { Polyurethane Board 75mm } \\
\text { Plaster 13mm }\end{array}$ & 0.31 \\
\hline External Glazing & $\begin{array}{l}\text { Pilkington K Glass 6mm } \\
\text { Cavity } \\
\text { Clear Float Glass 6mm }\end{array}$ & 1.95 \\
\hline Internal Walls & $\begin{array}{l}\text { Plaster 13mm } \\
\text { Concrete Block 105mm } \\
\text { Plaster 13mm }\end{array}$ & 2.04 \\
\hline Internal Floor/Ceiling & Cast Concrete 400mm & 1.92 \\
\hline Flat Roof & $\begin{array}{l}\text { Stone Chippings 10mm } \\
\text { Felt/Bitumen Layers 5mm } \\
\text { Fibreboard Insulation 150mm } \\
\text { Cast Concrete 100mm }\end{array}$ & 0.22 \\
\hline
\end{tabular}


Table 9 Heat gains used in the refurbishment dynamic thermal simulation

\begin{tabular}{|c|c|c|c|c|c|c|c|}
\hline \multirow[b]{2}{*}{ Space Name } & \multirow{2}{*}{$\begin{array}{c}\text { Equip } \\
\text { ment } \\
(W)\end{array}$} & \multicolumn{3}{|c|}{ Day-time 08:00 To 20:00 } & \multicolumn{3}{|c|}{ Night-time 20:00 To 08:00 } \\
\hline & & $\begin{array}{l}\text { Lighting } \\
\text { (W) }\end{array}$ & $\begin{array}{l}\text { Occupancy } \\
\text { (W) }\end{array}$ & $\begin{array}{l}\text { Density } \\
\left(W / m^{2}\right)\end{array}$ & $\begin{array}{l}\text { Lighting } \\
\text { (W) }\end{array}$ & $\begin{array}{l}\text { Occupancy } \\
\text { (W) }\end{array}$ & $\begin{array}{l}\text { Density } \\
\left(\mathrm{W} / \mathbf{m}^{2}\right)\end{array}$ \\
\hline GF Consulting Room 2a & 230 & 107 & 98 & 28 & 0 & 0 & 0 \\
\hline GF Consulting Room 2b & 230 & 107 & 98 & 28 & 0 & 0 & 0 \\
\hline GF Consulting Room 3a & 230 & 98 & 90 & 30 & 0 & 0 & 0 \\
\hline GF Consulting Room 3b & 230 & 98 & 90 & 30 & 0 & 0 & 0 \\
\hline GF Corridor $1 \mathrm{a}$ & 0 & 571 & 0 & 7 & 400 & 0 & 5 \\
\hline GF Corridor $1 \mathrm{~b}$ & 0 & 571 & 0 & 7 & 400 & 0 & 5 \\
\hline GF Toilets 1a & 0 & 214 & 0 & 7 & 150 & 0 & 5 \\
\hline GF Toilets $1 \mathrm{~b}$ & 0 & 214 & 0 & 7 & 150 & 0 & 5 \\
\hline GF Treatment Room 1a & 700 & 189 & 174 & 39 & 132 & 122 & 35 \\
\hline GF Treatment Room $1 b$ & 700 & 189 & 174 & 39 & 132 & 122 & 35 \\
\hline GF Ultrasound Room 1a & 600 & 123 & 113 & 48 & 86 & 79 & 44 \\
\hline GF Ultrasound Room 1b & 600 & 123 & 113 & 48 & 86 & 79 & 44 \\
\hline GF Consulting Room 1a & 230 & 159 & 146 & 24 & 0 & 0 & 0 \\
\hline GF Consulting Room 1b & 230 & 159 & 146 & 24 & 0 & 0 & 0 \\
\hline FF Four Bed Ward 1a & 400 & 362 & 332 & 21 & 253 & 233 & 17 \\
\hline FF Four Bed Ward 1b & 400 & 362 & 332 & 21 & 253 & 233 & 17 \\
\hline FF Four Bed Ward 2a & 400 & 362 & 332 & 21 & 253 & 233 & 17 \\
\hline FF Four Bed Ward 2b & 400 & 362 & 332 & 21 & 253 & 233 & 17 \\
\hline FF Four Bed Ward 3a & 400 & 362 & 332 & 21 & 253 & 233 & 17 \\
\hline FF Four Bed Ward 3b & 400 & 362 & 332 & 21 & 253 & 233 & 17 \\
\hline SF Delivery Room 1a & 330 & 242 & 222 & 23 & 169 & 155 & 19 \\
\hline SF Delivery Room 1b & 330 & 261 & 239 & 22 & 182 & 168 & 18 \\
\hline SF Four Bed Ward 1a & 400 & 362 & 332 & 21 & 253 & 233 & 17 \\
\hline SF Four Bed Ward 1b & 400 & 362 & 332 & 21 & 253 & 233 & 17 \\
\hline TF Four Bed Ward 1a & 400 & 343 & 315 & 22 & 240 & 220 & 18 \\
\hline TF Four Bed Ward 1b & 400 & 343 & 315 & 22 & 240 & 220 & 18 \\
\hline TF Four Bed Ward 2a & 400 & 343 & 315 & 22 & 240 & 220 & 18 \\
\hline TF Four Bed Ward 2b & 400 & 343 & 315 & 22 & 240 & 220 & 18 \\
\hline FF High Dependency 1a & 5800 & 395 & 363 & 116 & 277 & 254 & 112 \\
\hline FF High Dependency 1b & 5800 & 395 & 363 & 116 & 277 & 254 & 112 \\
\hline
\end{tabular}


Table 10 Ventilation modes used in the refurbishment dynamic thermal simulation model

\begin{tabular}{|c|c|c|c|c|c|c|c|c|}
\hline & \multicolumn{8}{|c|}{ Ventilation Scheme } \\
\hline & \multicolumn{2}{|c|}{ As-built (Case 1) } & \multicolumn{2}{|c|}{ Case 2} & \multicolumn{2}{|c|}{ Case 3} & \multicolumn{2}{|c|}{ Case 4} \\
\hline Room & $\begin{array}{c}\text { May to } \\
\text { Sept }\end{array}$ & $\begin{array}{l}\text { Oct to } \\
\text { April }\end{array}$ & $\begin{array}{c}\text { May to } \\
\text { Sept }\end{array}$ & $\begin{array}{c}\text { Oct to } \\
\text { April }\end{array}$ & $\begin{array}{c}\text { May to } \\
\text { Sept }\end{array}$ & $\begin{array}{l}\text { Oct to } \\
\text { April }\end{array}$ & $\begin{array}{c}\text { May to } \\
\text { Sept }\end{array}$ & $\begin{array}{l}\text { Oct to } \\
\text { April } \\
\end{array}$ \\
\hline GF Consulting Room 1a & MV & SSV & ANV & ANV & FANV & FANV & $\mathrm{M} 1(\mathrm{~V}+\mathrm{C})$ & $\mathrm{M} 1(\mathrm{~V}+\mathrm{C})$ \\
\hline GF Consulting Room 1b & MV & SSV & ANV & ANV & FANV & FANV & $\mathrm{M} 1(\mathrm{~V}+\mathrm{C})$ & $\mathrm{M} 1(\mathrm{~V}+\mathrm{C})$ \\
\hline FF Four Bed Ward 1a & MV & SSV & ANV & ANV & FANV & FANV & $\mathrm{M} 1(\mathrm{~V}+\mathrm{C})$ & $\mathrm{M} 1(\mathrm{~V}+\mathrm{C})$ \\
\hline FF Four Bed Ward 1b & MV & SSV & ANV & ANV & FANV & FANV & $\mathrm{M} 1(\mathrm{~V}+\mathrm{C})$ & $\mathrm{M} 1(\mathrm{~V}+\mathrm{C})$ \\
\hline FF Four Bed Ward 2a & MV & SSV & ANV & ANV & FANV & FANV & $\mathrm{M} 1(\mathrm{~V}+\mathrm{C})$ & $\mathrm{M} 1(\mathrm{~V}+\mathrm{C})$ \\
\hline FF Four Bed Ward 2b & MV & SSV & ANV & ANV & FANV & FANV & $\mathrm{M} 1(\mathrm{~V}+\mathrm{C})$ & $\mathrm{M} 1(\mathrm{~V}+\mathrm{C})$ \\
\hline FF Four Bed Ward 3a & MV & SSV & ANV & ANV & FANV & FANV & $\mathrm{M} 1(\mathrm{~V}+\mathrm{C})$ & $\mathrm{M} 1(\mathrm{~V}+\mathrm{C})$ \\
\hline FF Four Bed Ward 3b & MV & SSV & ANV & ANV & FANV & FANV & $\mathrm{M} 1(\mathrm{~V}+\mathrm{C})$ & $\mathrm{M} 1(\mathrm{~V}+\mathrm{C})$ \\
\hline SF Delivery Room 1a & MV & MV & ANV & ANV & FANV & FANV & $\mathrm{M} 1(\mathrm{~V}+\mathrm{C})$ & $\mathrm{M} 1(\mathrm{~V}+\mathrm{C})$ \\
\hline SF Delivery Room 1b & MV & MV & ANV & ANV & FANV & FANV & $\mathrm{M} 1(\mathrm{~V}+\mathrm{C})$ & $\mathrm{M} 1(\mathrm{~V}+\mathrm{C})$ \\
\hline SF Four Bed Ward 1a & MV & SSV & ANV & $\mathrm{ANV}$ & FANV & FANV & $\mathrm{M} 1(\mathrm{~V}+\mathrm{C})$ & $\mathrm{M} 1(\mathrm{~V}+\mathrm{C})$ \\
\hline SF Four Bed Ward 1b & MV & SSV & ANV & ANV & FANV & FANV & $\mathrm{M} 1(\mathrm{~V}+\mathrm{C})$ & $\mathrm{M} 1(\mathrm{~V}+\mathrm{C})$ \\
\hline TF Four Bed Ward 1a & MV & SSV & ANV & ANV & FANV & FANV & $\mathrm{M} 1(\mathrm{~V}+\mathrm{C})$ & $\mathrm{M} 1(\mathrm{~V}+\mathrm{C})$ \\
\hline TF Four Bed Ward 1b & MV & SSV & ANV & ANV & FANV & FANV & $\mathrm{M} 1(\mathrm{~V}+\mathrm{C})$ & $\mathrm{M} 1(\mathrm{~V}+\mathrm{C})$ \\
\hline TF Four Bed Ward 2a & MV & SSV & ANV & ANV & FANV & FANV & $\mathrm{M} 1(\mathrm{~V}+\mathrm{C})$ & $\mathrm{M} 1(\mathrm{~V}+\mathrm{C})$ \\
\hline TF Four Bed Ward 2b & MV & SSV & ANV & ANV & FANV & FANV & $\mathrm{M} 1(\mathrm{~V}+\mathrm{C})$ & $\mathrm{M} 1(\mathrm{~V}+\mathrm{C})$ \\
\hline GF Consulting Room 2a & MV & SSV & $\mathrm{M} 2(\mathrm{~V}+\mathrm{C})$ & SSV & $\mathrm{M} 2(\mathrm{~V}+\mathrm{C})$ & SSV & $\mathrm{M} 2(\mathrm{~V}+\mathrm{C})$ & SSV \\
\hline GF Consulting Room $2 b$ & MV & SSV & $\mathrm{M} 2(\mathrm{~V}+\mathrm{C})$ & SSV & $\mathrm{M} 2(\mathrm{~V}+\mathrm{C})$ & SSV & $\mathrm{M} 2(\mathrm{~V}+\mathrm{C})$ & SSV \\
\hline GF Consulting Room 3a & MV & SSV & $\mathrm{M} 2(\mathrm{~V}+\mathrm{C})$ & SSV & $\mathrm{M} 2(\mathrm{~V}+\mathrm{C})$ & SSV & $\mathrm{M} 2(\mathrm{~V}+\mathrm{C})$ & SSV \\
\hline GF Consulting Room 3b & MV & SSV & $\mathrm{M} 2(\mathrm{~V}+\mathrm{C})$ & SSV & $\mathrm{M} 2(\mathrm{~V}+\mathrm{C})$ & SSV & $\mathrm{M} 2(\mathrm{~V}+\mathrm{C})$ & SSV \\
\hline GF Corridor 1a & MV & MV & $\mathrm{M} 2(\mathrm{~V}+\mathrm{C})$ & MV & $\mathrm{M} 2(\mathrm{~V}+\mathrm{C})$ & MV & $\mathrm{M} 2(\mathrm{~V}+\mathrm{C})$ & MV \\
\hline GF Corridor $1 b$ & MV & MV & $\mathrm{M} 2(\mathrm{~V}+\mathrm{C})$ & MV & $\mathrm{M} 2(\mathrm{~V}+\mathrm{C})$ & MV & $\mathrm{M} 2(\mathrm{~V}+\mathrm{C})$ & MV \\
\hline GF Toilets 1a & MV & MV & $\mathrm{M} 2(\mathrm{~V}+\mathrm{C})$ & MV & $\mathrm{M} 2(\mathrm{~V}+\mathrm{C})$ & MV & $\mathrm{M} 2(\mathrm{~V}+\mathrm{C})$ & MV \\
\hline GF Toilets $1 \mathrm{~b}$ & MV & MV & $\mathrm{M} 2(\mathrm{~V}+\mathrm{C})$ & MV & $\mathrm{M} 2(\mathrm{~V}+\mathrm{C})$ & MV & $\mathrm{M} 2(\mathrm{~V}+\mathrm{C})$ & MV \\
\hline GF Treatment Room 1a & MV & MV & $\mathrm{M} 2(\mathrm{~V}+\mathrm{C})$ & MV & $\mathrm{M} 2(\mathrm{~V}+\mathrm{C})$ & MV & $\mathrm{M} 2(\mathrm{~V}+\mathrm{C})$ & MV \\
\hline GF Treatment Room 1b & MV & MV & $\mathrm{M} 2(\mathrm{~V}+\mathrm{C})$ & MV & $\mathrm{M} 2(\mathrm{~V}+\mathrm{C})$ & MV & $\mathrm{M} 2(\mathrm{~V}+\mathrm{C})$ & MV \\
\hline GF Ultrasound Room 1a & MV & MV & $\mathrm{M} 2(\mathrm{~V}+\mathrm{C})$ & MV & $\mathrm{M} 2(\mathrm{~V}+\mathrm{C})$ & MV & $\mathrm{M} 2(\mathrm{~V}+\mathrm{C})$ & MV \\
\hline GF Ultrasound Room 1b & MV & MV & $\mathrm{M} 2(\mathrm{~V}+\mathrm{C})$ & MV & $\mathrm{M} 2(\mathrm{~V}+\mathrm{C})$ & MV & $\mathrm{M} 2(\mathrm{~V}+\mathrm{C})$ & MV \\
\hline FF High Dependency 1a & $\mathrm{M} 2(\mathrm{~V}+\mathrm{C})$ & $\mathrm{M} 2(\mathrm{~V}+\mathrm{C})$ & $\mathrm{M} 2(\mathrm{~V}+\mathrm{C})$ & $\mathrm{M} 2(\mathrm{~V}+\mathrm{C})$ & $\mathrm{M} 2(\mathrm{~V}+\mathrm{C})$ & $\mathrm{M} 2(\mathrm{~V}+\mathrm{C})$ & $\mathrm{M} 2(\mathrm{~V}+\mathrm{C})$ & $\mathrm{M} 2(\mathrm{~V}+\mathrm{C})$ \\
\hline FF High Dependency 1b & $\mathrm{M} 2(\mathrm{~V}+\mathrm{C})$ & $\mathrm{M} 2(\mathrm{~V}+\mathrm{C})$ & $\mathrm{M} 2(\mathrm{~V}+\mathrm{C})$ & $\mathrm{M} 2(\mathrm{~V}+\mathrm{C})$ & $\mathrm{M} 2(\mathrm{~V}+\mathrm{C})$ & $\mathrm{M} 2(\mathrm{~V}+\mathrm{C})$ & $\mathrm{M} 2(\mathrm{~V}+\mathrm{C})$ & $\mathrm{M} 2(\mathrm{~V}+\mathrm{C})$ \\
\hline
\end{tabular}

SSV single-sided natural ventilation

$\mathrm{M} 2(\mathrm{~V}+\mathrm{C}) \quad$ dedicated mechanical ventilation with mechanical cooling

ANV advanced natural ventilation

FANV fan-assisted natural ventilation

$\mathrm{M} 1(\mathrm{~V}+\mathrm{C}) \quad$ shared mechanical ventilation with shared mechanical cooling 
Table 11 Thermal performance predictions for case 2 (ANV refurbishment)

\begin{tabular}{|c|c|c|c|c|}
\hline \multirow[b]{2}{*}{ Room } & \multicolumn{4}{|c|}{ Hours over $28^{\circ} \mathrm{C}$} \\
\hline & 2005 & 2020 & 2050 & 2080 \\
\hline GF Consulting Room 1a & 6 & 2 & 28 & 109 \\
\hline GF Consulting Room $1 \mathrm{~b}$ & 4 & 2 & 27 & 100 \\
\hline FF Four Bed Ward 1a & 35 & 13 & 43 & 284 \\
\hline FF Four Bed Ward 1b & 31 & 12 & 40 & 258 \\
\hline FF Four Bed Ward 2a & 36 & 13 & 47 & 293 \\
\hline FF Four Bed Ward 2b & 32 & 12 & 40 & 267 \\
\hline FF Four Bed Ward 3a & 39 & 19 & 60 & 312 \\
\hline FF Four Bed Ward 3b & 37 & 14 & 55 & 285 \\
\hline SF Delivery Room 1a & 45 & 17 & 83 & 444 \\
\hline SF Delivery Room $1 \mathrm{~b}$ & 40 & 12 & 72 & 421 \\
\hline SF Four Bed Ward 1a & 37 & 13 & 52 & 314 \\
\hline SF Four Bed Ward 1b & 34 & 12 & 46 & 291 \\
\hline TF Four Bed Ward 1a & 46 & 24 & 117 & 458 \\
\hline TF Four Bed Ward 1b & 44 & 23 & 108 & 449 \\
\hline TF Four Bed Ward 2a & 45 & 24 & 117 & 454 \\
\hline TF Four Bed Ward 2b & 43 & 23 & 105 & 437 \\
\hline GF Consulting Room 2a & $\mathbf{0}$ & $\mathbf{0}$ & $\mathbf{0}$ & $\mathbf{0}$ \\
\hline GF Consulting Room $2 b$ & 0 & $\mathbf{0}$ & 0 & $\mathbf{0}$ \\
\hline GF Consulting Room 3a & 4 & $\mathbf{0}$ & $\mathbf{0}$ & $\mathbf{0}$ \\
\hline GF Consulting Room 3b & 15 & $\mathbf{0}$ & $\mathbf{0}$ & $\mathbf{0}$ \\
\hline GF Corridor 1a & 0 & $\mathbf{0}$ & $\mathbf{0}$ & $\mathbf{0}$ \\
\hline GF Corridor $1 \mathrm{~b}$ & 0 & 0 & $\mathbf{0}$ & $\mathbf{0}$ \\
\hline GF Toilets 1a & 0 & 0 & $\mathbf{0}$ & $\mathbf{0}$ \\
\hline GF Toilets $1 b$ & $\mathbf{0}$ & 0 & $\mathbf{0}$ & $\mathbf{0}$ \\
\hline GF Treatment Room 1a & $\mathbf{0}$ & 0 & 0 & $\mathbf{0}$ \\
\hline GF Treatment Room $1 b$ & $\mathbf{0}$ & $\mathbf{0}$ & $\mathbf{0}$ & $\mathbf{0}$ \\
\hline GF Ultrasound Room 1a & $\mathbf{0}$ & $\mathbf{0}$ & 0 & $\mathbf{0}$ \\
\hline GF Ultrasound Room $1 \mathrm{~b}$ & $\mathbf{0}$ & $\mathbf{0}$ & 0 & $\mathbf{0}$ \\
\hline FF High Dependency 1a & $\mathbf{0}$ & $\mathbf{0}$ & 0 & $\mathbf{0}$ \\
\hline FF High Dependency $1 \mathrm{~b}$ & 0 & 0 & 0 & 0 \\
\hline
\end{tabular}


Table 12 Thermal performance predictions for case 3 (FANV refurbishment)

\begin{tabular}{|c|c|c|c|c|}
\hline \multirow[b]{2}{*}{ Room } & \multicolumn{4}{|c|}{ Hours over $28^{\circ} \mathrm{C}$} \\
\hline & 2005 & 2020 & 2050 & 2080 \\
\hline GF Consulting Room 1a & 0 & 2 & 38 & 142 \\
\hline GF Consulting Room $1 \mathrm{~b}$ & $\mathbf{0}$ & $\mathbf{0}$ & 25 & 123 \\
\hline FF Four Bed Ward 1a & 0 & 9 & 44 & 282 \\
\hline FF Four Bed Ward 1b & 0 & 9 & 46 & 287 \\
\hline FF Four Bed Ward 2a & 0 & 9 & 46 & 286 \\
\hline FF Four Bed Ward 2b & 0 & 9 & 48 & 290 \\
\hline FF Four Bed Ward 3a & 5 & 14 & 61 & 313 \\
\hline FF Four Bed Ward 3b & 4 & 19 & 93 & 490 \\
\hline SF Delivery Room 1a & $\mathbf{0}$ & 11 & 60 & 415 \\
\hline SF Delivery Room 1b & 0 & 13 & 67 & 439 \\
\hline SF Four Bed Ward 1a & 0 & 9 & 46 & 301 \\
\hline SF Four Bed Ward 1b & 0 & 9 & 52 & 305 \\
\hline TF Four Bed Ward 1a & 8 & 19 & 81 & 406 \\
\hline TF Four Bed Ward 1b & 8 & 20 & 84 & 447 \\
\hline TF Four Bed Ward 2a & 8 & 19 & 75 & 404 \\
\hline TF Four Bed Ward 2b & 8 & 22 & 87 & 438 \\
\hline GF Consulting Room 2a & $\mathbf{0}$ & $\mathbf{0}$ & $\mathbf{0}$ & $\mathbf{0}$ \\
\hline GF Consulting Room $2 b$ & 0 & $\mathbf{0}$ & $\mathbf{0}$ & $\mathbf{0}$ \\
\hline GF Consulting Room 3a & $\mathbf{0}$ & $\mathbf{0}$ & $\mathbf{0}$ & $\mathbf{0}$ \\
\hline GF Consulting Room 3b & $\mathbf{0}$ & $\mathbf{0}$ & $\mathbf{0}$ & $\mathbf{0}$ \\
\hline GF Corridor 1a & 0 & $\mathbf{0}$ & $\mathbf{0}$ & $\mathbf{0}$ \\
\hline GF Corridor $1 \mathrm{~b}$ & $\mathbf{0}$ & $\mathbf{0}$ & $\mathbf{0}$ & $\mathbf{0}$ \\
\hline GF Toilets 1a & $\mathbf{0}$ & 0 & $\mathbf{0}$ & $\mathbf{0}$ \\
\hline GF Toilets $1 b$ & $\mathbf{0}$ & 0 & $\mathbf{0}$ & $\mathbf{0}$ \\
\hline GF Treatment Room 1a & $\mathbf{0}$ & 0 & 0 & $\mathbf{0}$ \\
\hline GF Treatment Room 1b & $\mathbf{0}$ & $\mathbf{0}$ & 0 & $\mathbf{0}$ \\
\hline GF Ultrasound Room 1a & $\mathbf{0}$ & $\mathbf{0}$ & 0 & $\mathbf{0}$ \\
\hline GF Ultrasound Room $1 \mathrm{~b}$ & $\mathbf{0}$ & $\mathbf{0}$ & 0 & $\mathbf{0}$ \\
\hline FF High Dependency 1a & $\mathbf{0}$ & $\mathbf{0}$ & $\mathbf{0}$ & $\mathbf{0}$ \\
\hline FF High Dependency $1 b$ & 0 & 0 & 0 & 0 \\
\hline
\end{tabular}




\section{Figure Captions}

Figure 1. Maternity wing viewed from south-west showing entrance lobby and plant space on roof

Figure 2. Photograph showing main entrance and highly glazed elevation with concrete mullions

Figure 3. Section through maternity wing (as-built) showing environmental characteristics during summer time operation.

(1) fabric heat losses/gains

(2) lightweight surfaces

(3) uncontrolled infiltration

(4) direct solar gain through large areas of unshaded glazing

(5) and (6) internal heat gains from patients, staff, equipment and lighting

Figure 4. Section through maternity wing (as-built) showing environmental characteristics during winter time operation.

(1) poorly insulated roof slab radiates heat to night sky

(2) heat loss through poorly insulated solid envelope, glazing and non-airtight construction

(3) dry resultant temperature (operative temperature) is lower than air temperature due to cold surfaces

(4) ill-fitting single glazing causes uncontrollable infiltration and cold downdraughts for patients

(5) conductive heat losses through uninsulated ground floor slab

(6) wind effects increase heat loss from building

(7) glare from low-level sun results in use of blinds which reduces daylight resulting in greater use of artificial lighting

(8) and (9) internal heat gains from patients, staff, equipment and lighting

Figure 5. Distribution of total solar irradiation on west facing elevation for mid June (top - simple model, bottom - building as-built).

Figure 6. Daylight model predictions for as-built construction (top left: model geometry, top right: mid March using CIE clear sky without sun, bottom left: mid June using CIE sunny sky, bottom right: mid December using CIE overcast sky.

Figure 7a. Ground floor plan showing rooms modelled in dynamic thermal simulation

Figure $7 b$. First floor plan showing rooms modelled in dynamic thermal simulation

Figure 7c. Second floor plan showing rooms modelled in dynamic thermal simulation

Figure $7 \mathrm{~d}$. Third floor plan showing rooms modelled in dynamic thermal simulation

Figure 8. Future temperatures predicted by morphing algorithm

Figure 9. Refurbishment proposal showing replacement of existing elevations.

(1) H-pot terminal 
(2) Exhaust plenum

(3) Windows shaded by being recessed in thick wall

(4) Air inlet "ring" duct and mechanical supply

(5) Passive air inlets

(6) Air supply "drop" to ground floor

(7) Control dampers

(8) Mechanical extract fan with recirculation to central AHU

(9) Vitiated air gathered in return air shaft and exhausted through heat exchanger

(10) AHU with heat recovery

(11) Mechanical supply of fresh air

(12) Air exhausted through fan-assisted terminals in passive mode

(13) Return shaft

(14) Dedicated exhaust shaft

(15) Supply shaft

(16) Primary supply shaft

(17) Air enters through control dampers in soffit

Figure 10. Refurbishment proposal showing ventilation strategy for a 4-bed ward

(1) Modular low-level inlets

(2) Air exhaust bulkheads could be extended to provide separate exhaust openings closer to outer and inner beds

(3) Suspended ceiling removed in wards

ME Mechanical extract

MS Balanced mechanical supply with heat recovery

Figure 11. Distribution of total solar irradiation on west facing elevation for refurbishment design (top - mid June, bottom - mid December).

Figure 12. Daylight model predictions for refurbishment construction (top left: model geometry, top right: mid March using CIE clear sky without sun, bottom left: mid June using CIE sunny sky, bottom right: mid December using CIE overcast sky.

Figure 13. Predicted total annual energy consumption (GJ/100 $\mathrm{m}^{3}$ heated volume)

Figure 14. Predicted total annual energy consumption by usage (MWh)

Figure 15. Predicted carbon generated (tonnes CO2) 


1
2
3
4
5
6
7
8
9
10
11
12
13
14
15
16
17
18
19
20
21
22
23
24
25
26
27
28
29
30
31
32
33
34
35
36
37
38
39
40
41
42
43
44
45
46
47
48
49
50
51
52
53
54
55
56
57
59
60

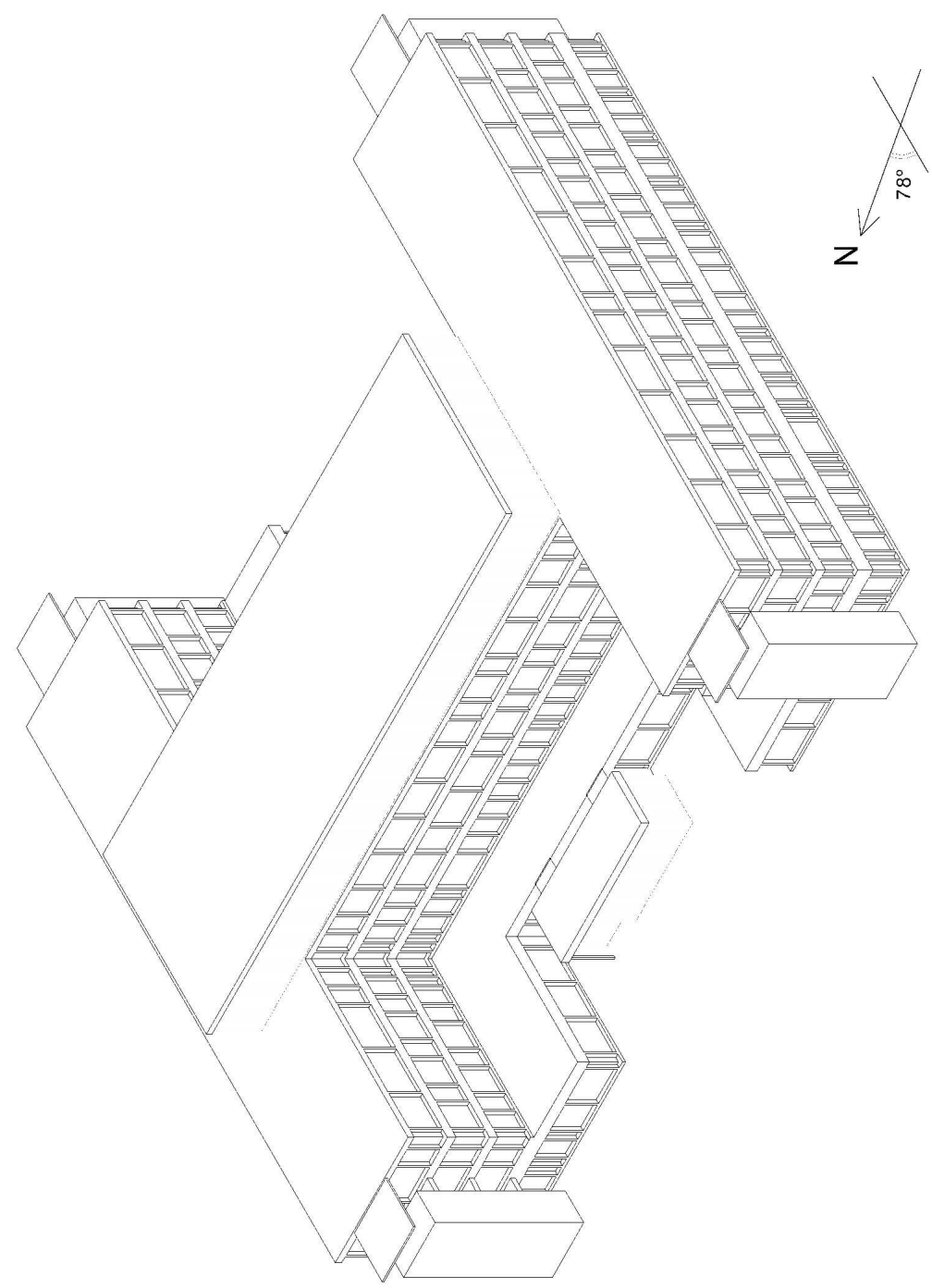

Figure 1 $209 \times 297 \mathrm{~mm}(600 \times 600 \mathrm{DPI})$

URL: http://mc.manuscriptcentral.com/tbps 


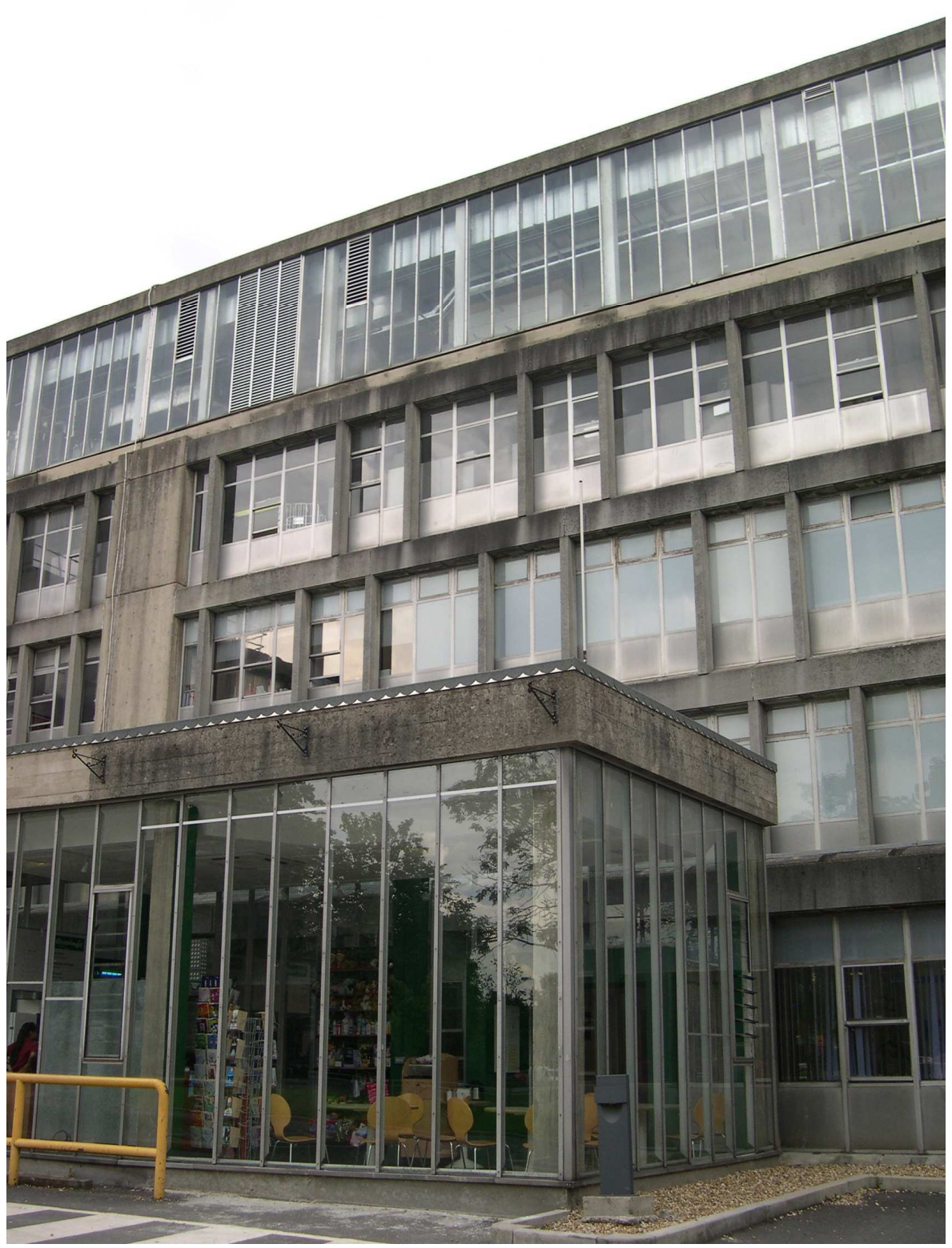

Figure 2

$601 \times 801 \mathrm{~mm}(72 \times 72$ DPI $)$ 


1
2
3
4
5
6
7
8
9
10
11
12
13
14
15
16
17
18
19
20
21
22
23
24
25
26
27
28
29
30
31
32
33
34
35
36
37
38
39
40
41
42
43
44
45
46
47
48
49
50
51
52
53
54
55
56
57
58
60

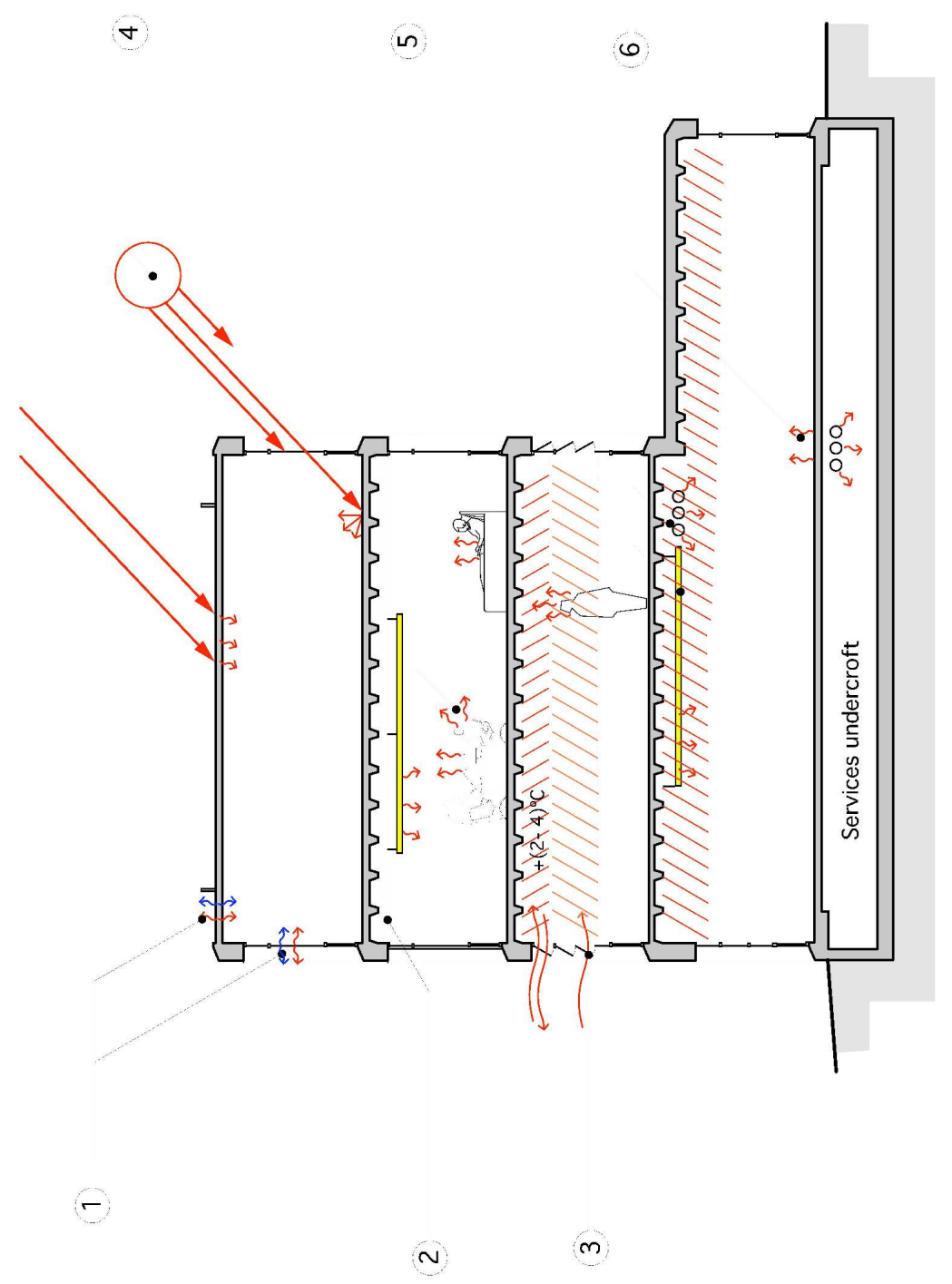

Figure 3 $209 \times 297 \mathrm{~mm}(600 \times 600 \mathrm{DPI})$

URL: http://mc.manuscriptcentral.com/tbps 


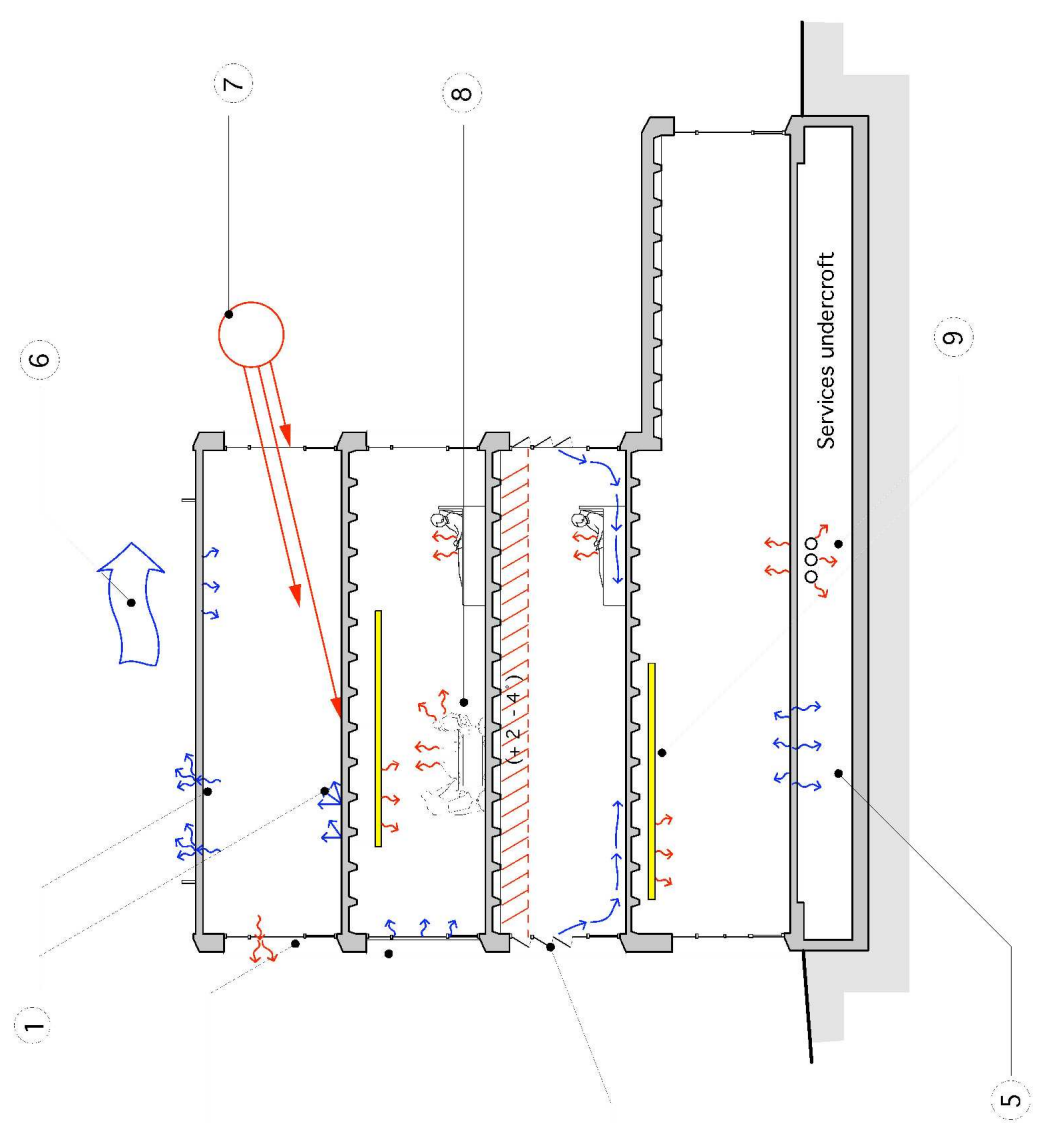

m)

$\sim$

Figure 4 $209 \times 297 m m(600 \times 600$ DPI $)$

URL: http://mc.manuscriptcentral.com/tbps 

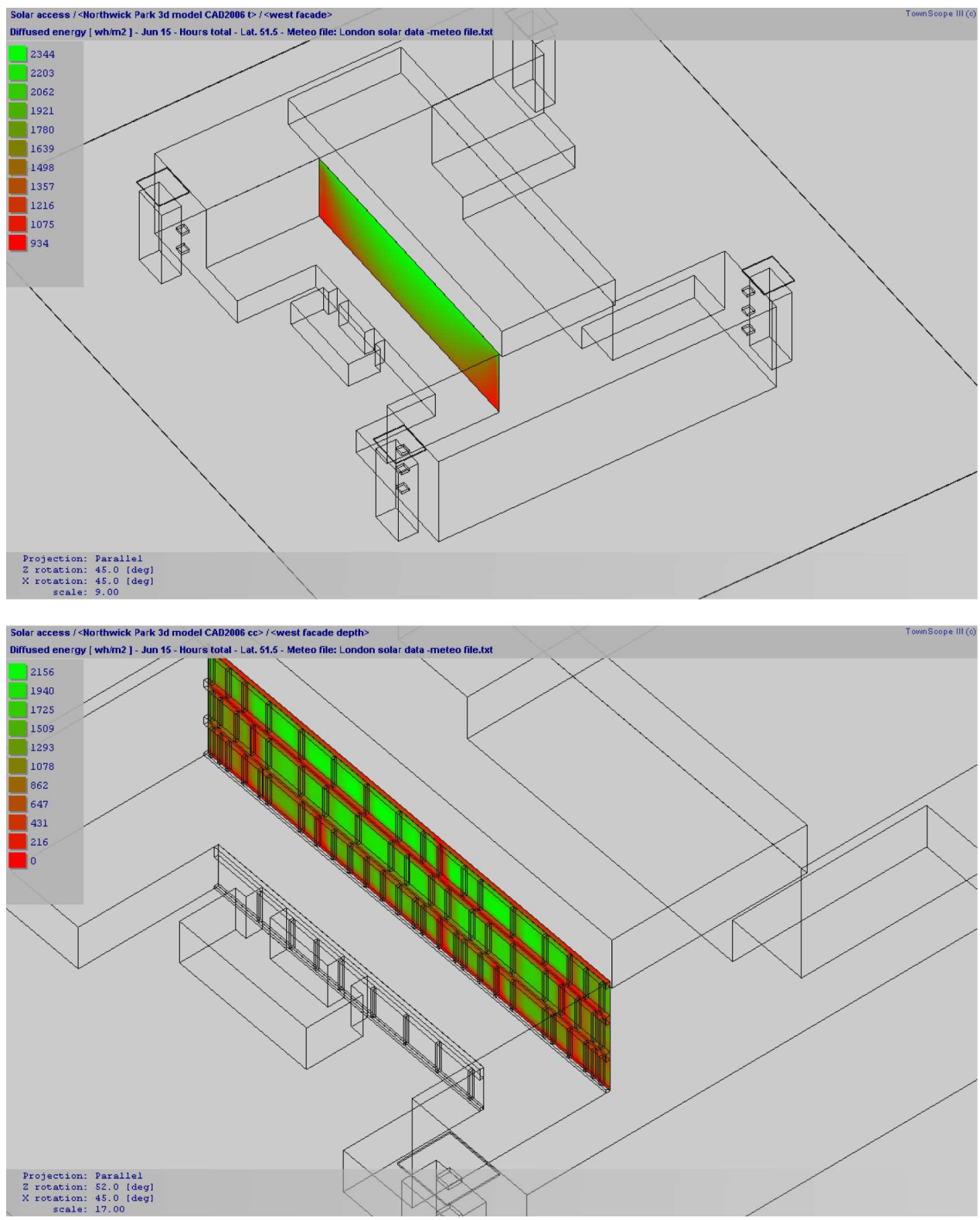

Figure 5 $146 \times 182 \mathrm{~mm}(300 \times 300$ DPI $)$ 

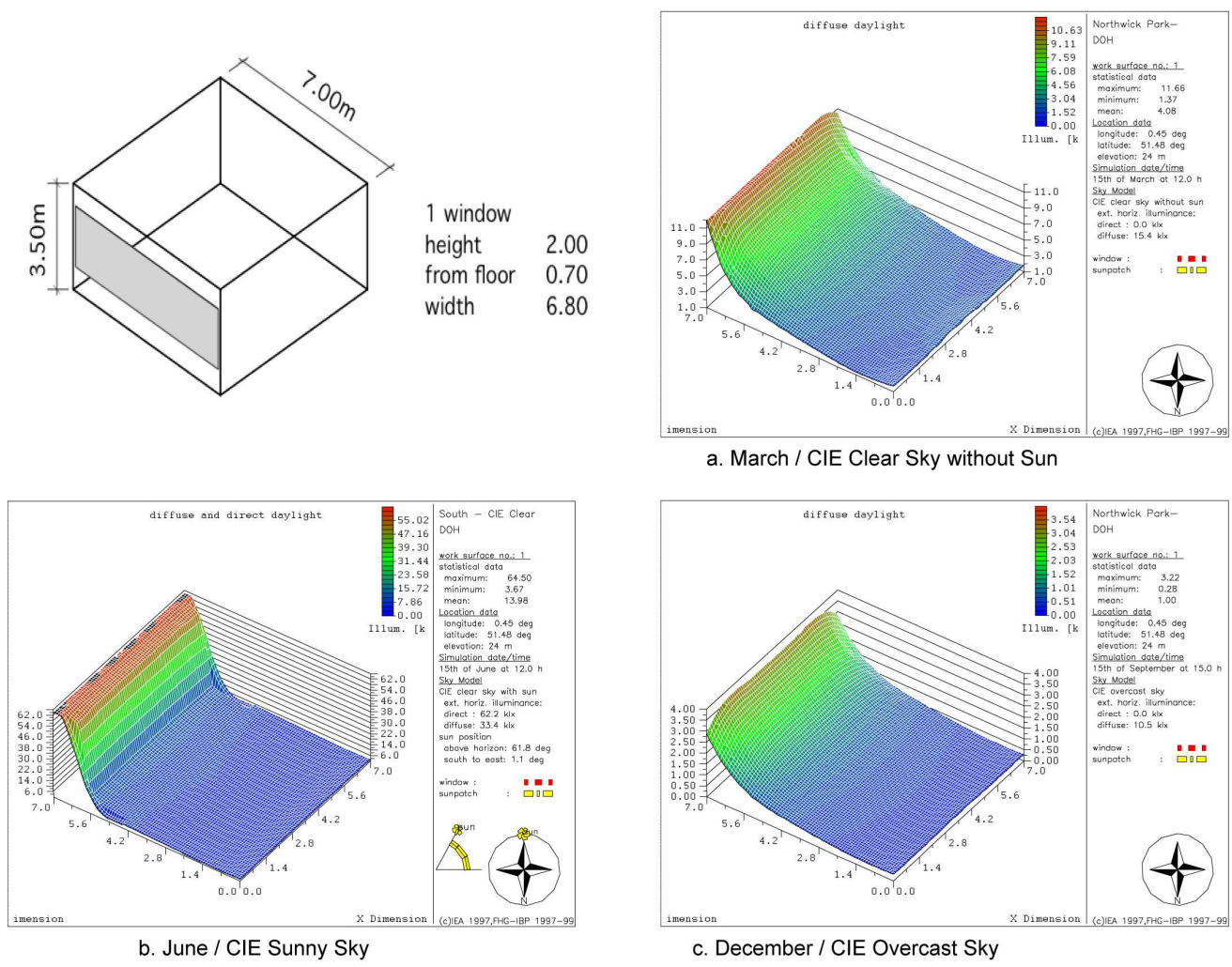

Figure 6

$182 \times 142 \mathrm{~mm}(300 \times 300$ DPI $)$ 


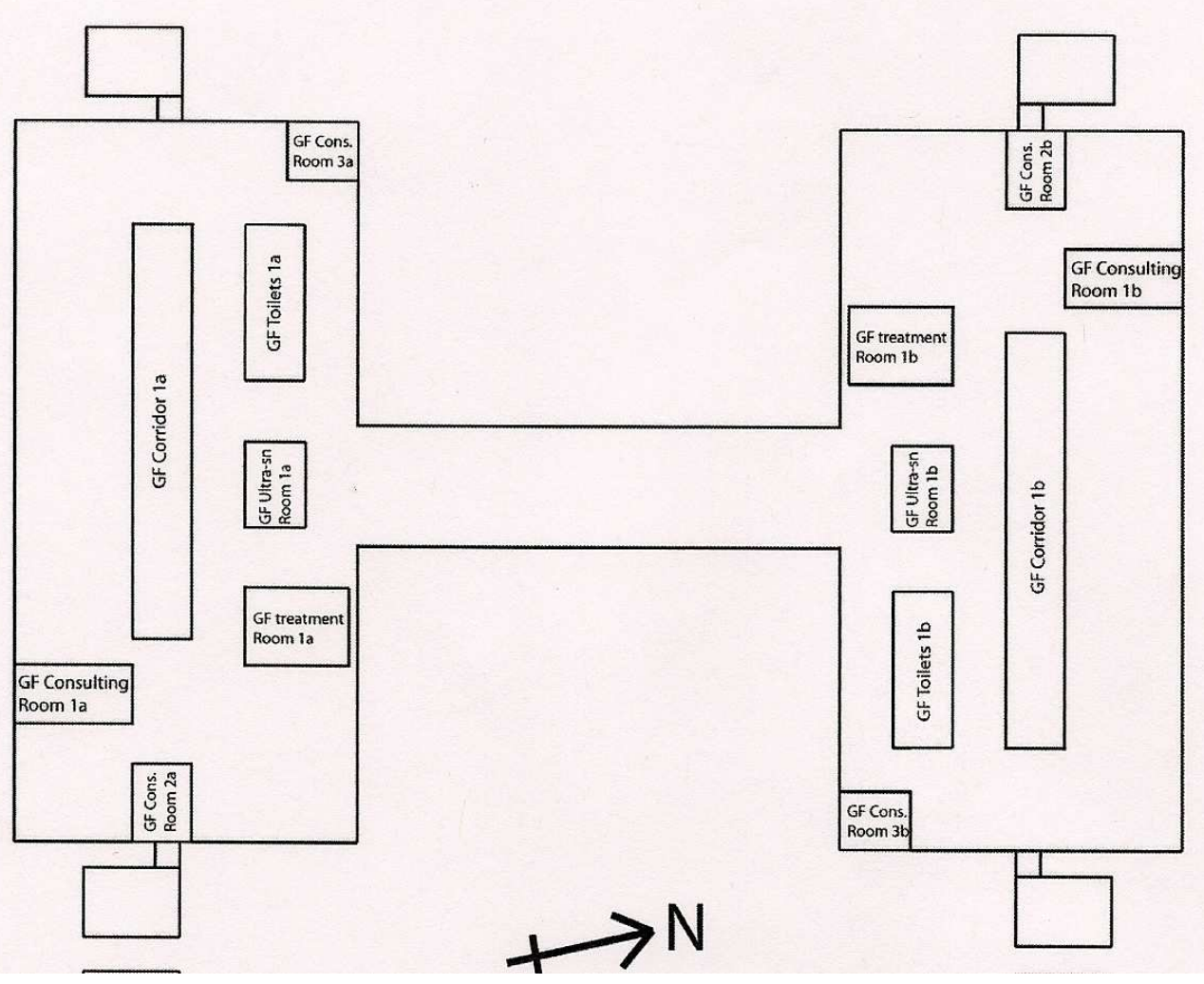

Figure $7 \mathrm{a}$

$148 \times 117 \mathrm{~mm}(200 \times 200$ DPI $)$ 


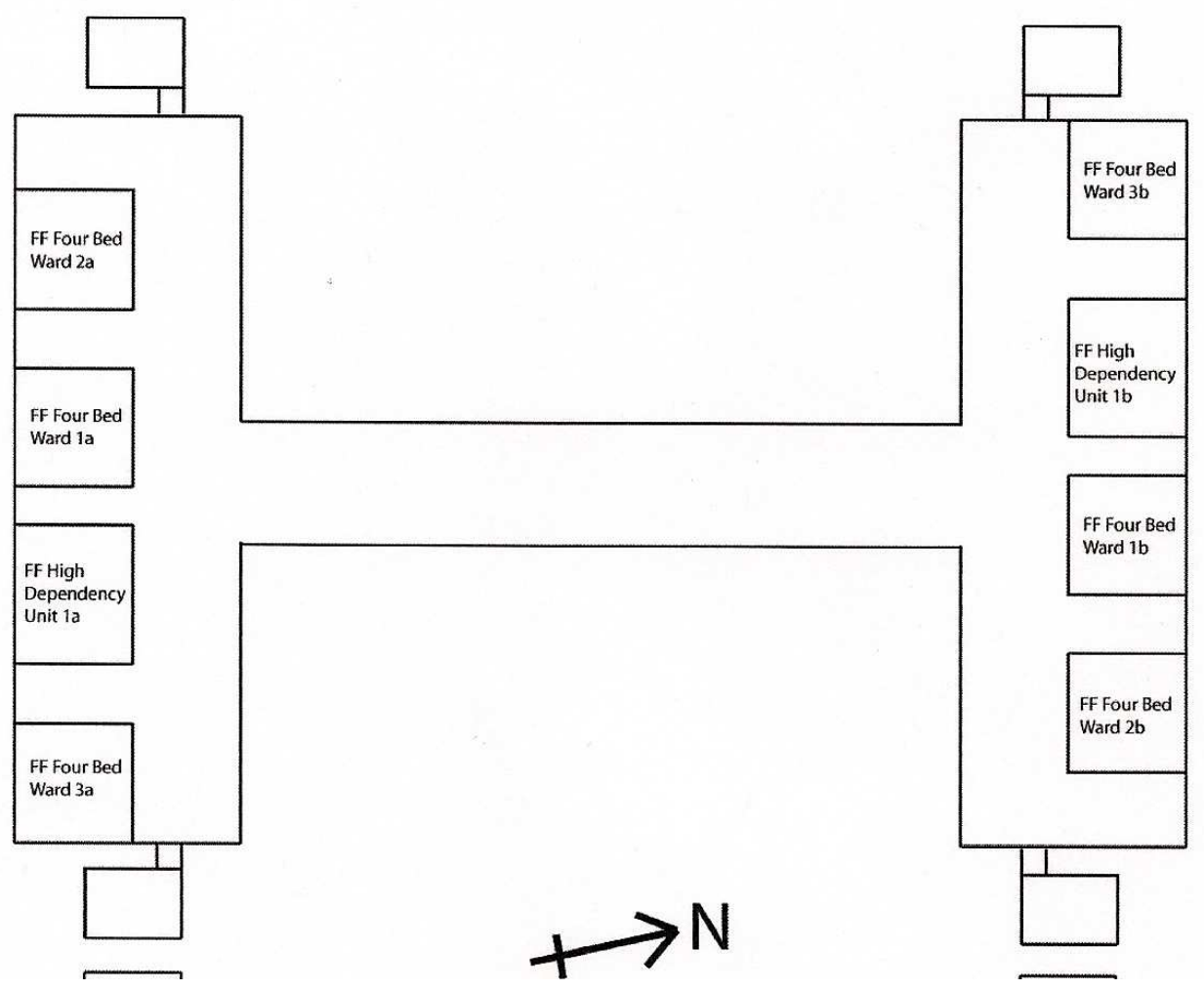

Figure $7 \mathrm{~b}$

$151 \times 117 \mathrm{~mm}(200 \times 200$ DPI $)$

URL: http://mc.manuscriptcentral.com/tbps 


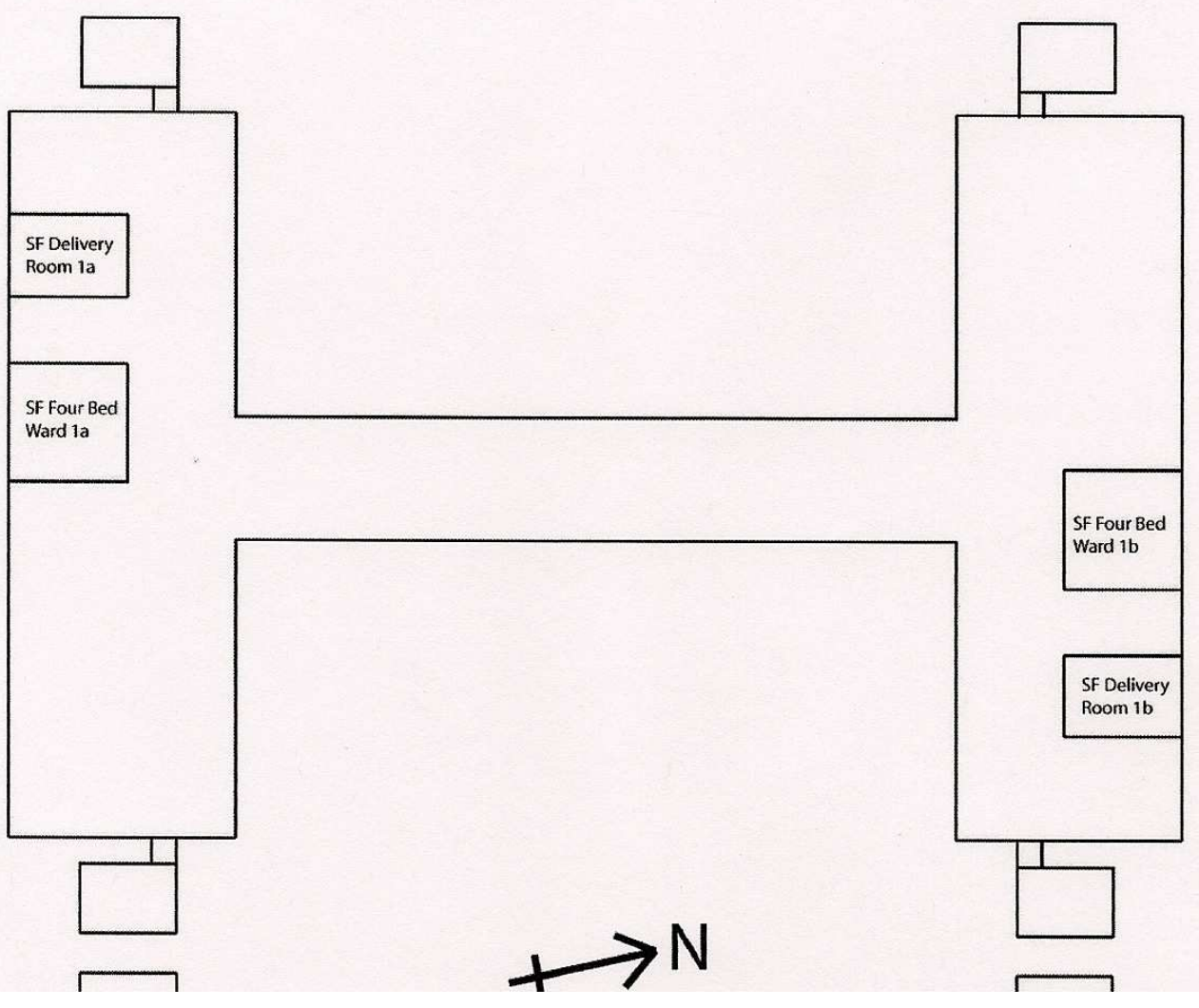

Figure 7c

$147 \times 119 \mathrm{~mm}(200 \times 200$ DPI $)$ 


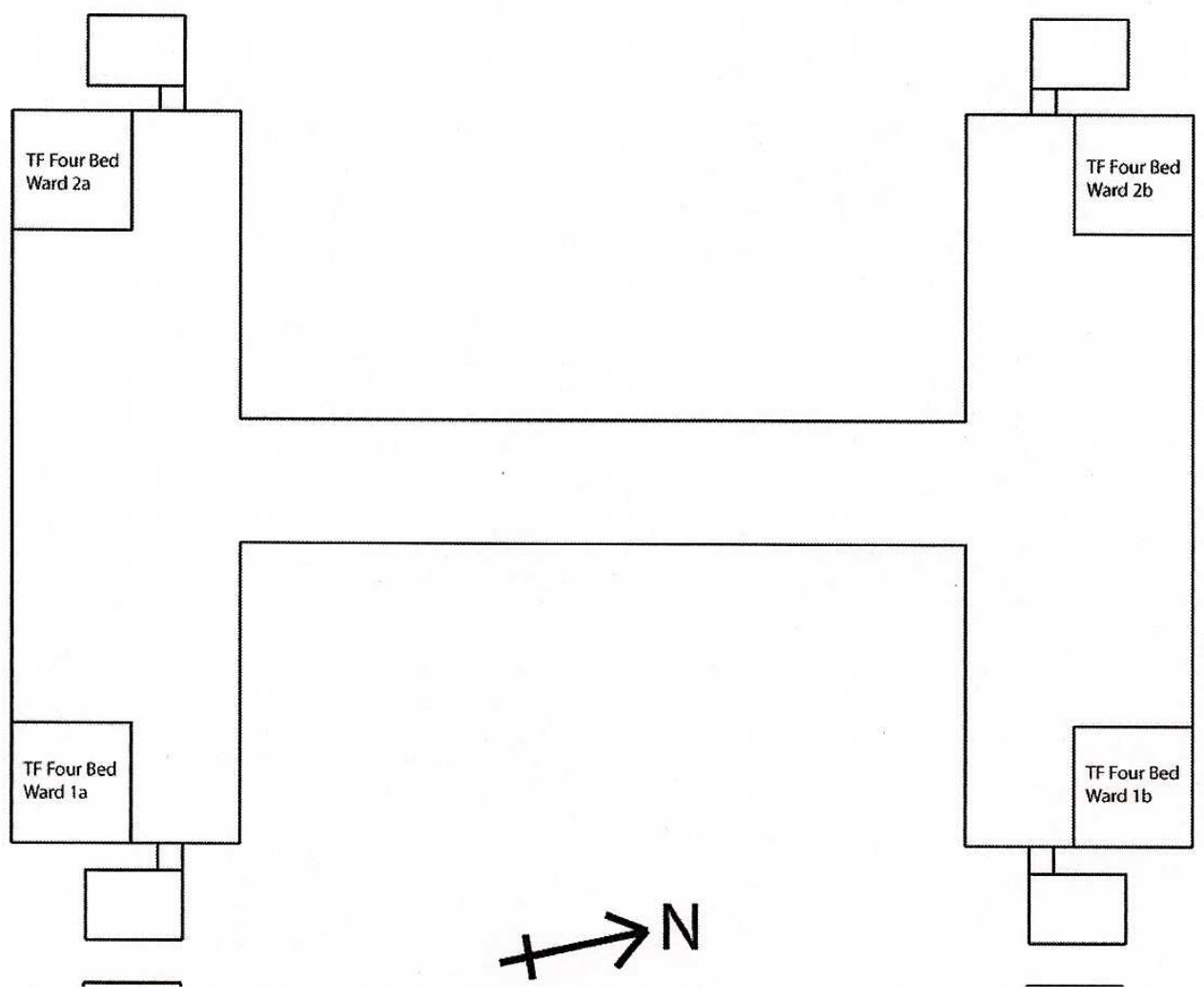

Figure $7 d$

$146 \times 117 \mathrm{~mm}(200 \times 200$ DPI $)$

URL: http://mc.manuscriptcentral.com/tbps 


1
1
3
4
5
6
7
8
9
10
11
12
13
14
15
16
17
18
19
20
21
22
23
24
25
26
27
28
29
30
31
32
33
34
35
36
37
38
39
40
41
42
43
44
55
50
56
57
48
59
50
51
53
50

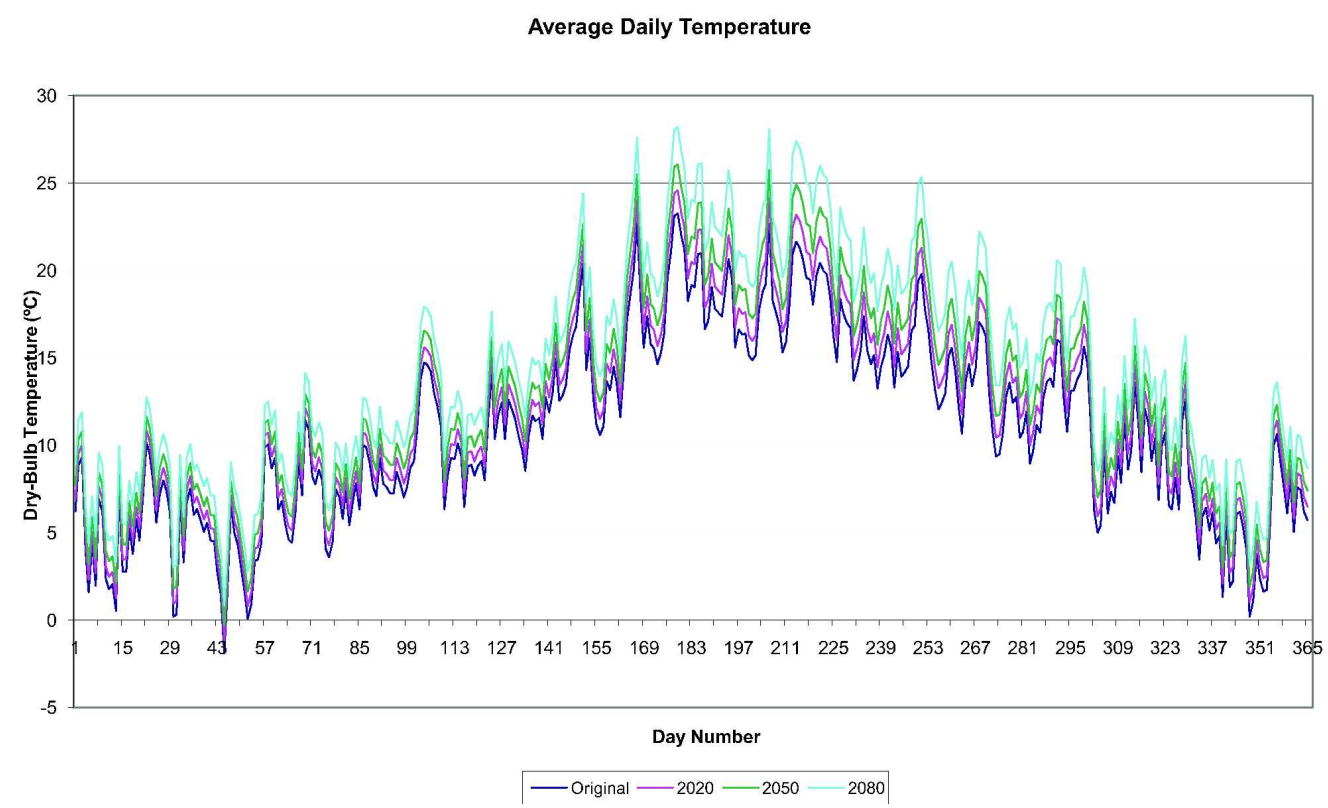

Figure 8

$249 \times 151 \mathrm{~mm}(600 \times 600 \mathrm{DPI})$ 


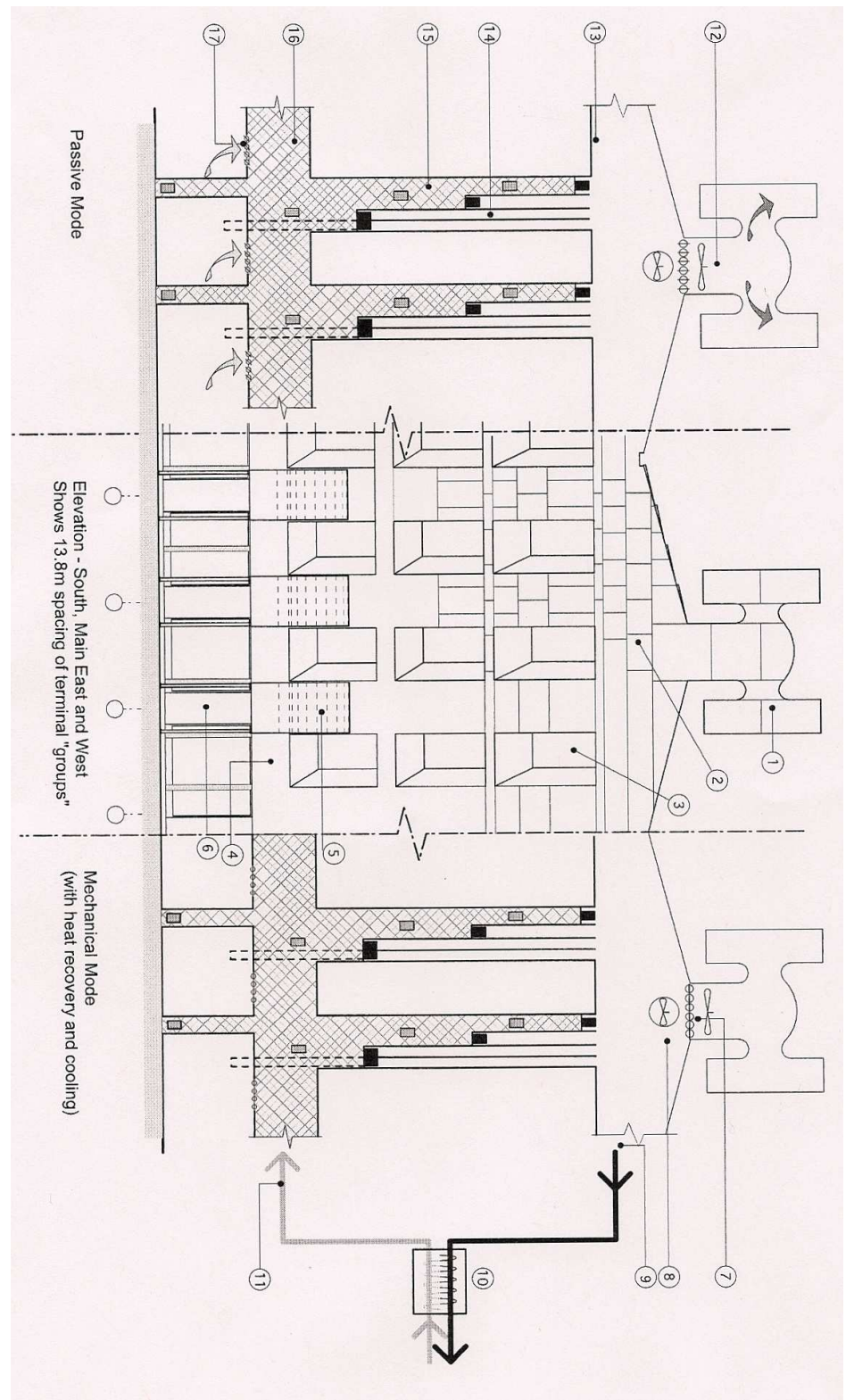

Figure 9

$145 \times 243 \mathrm{~mm}(200 \times 200$ DPI $)$ 
Figure 10 $209 \times 297 \mathrm{~mm}(600 \times 600$ DPI $)$ 

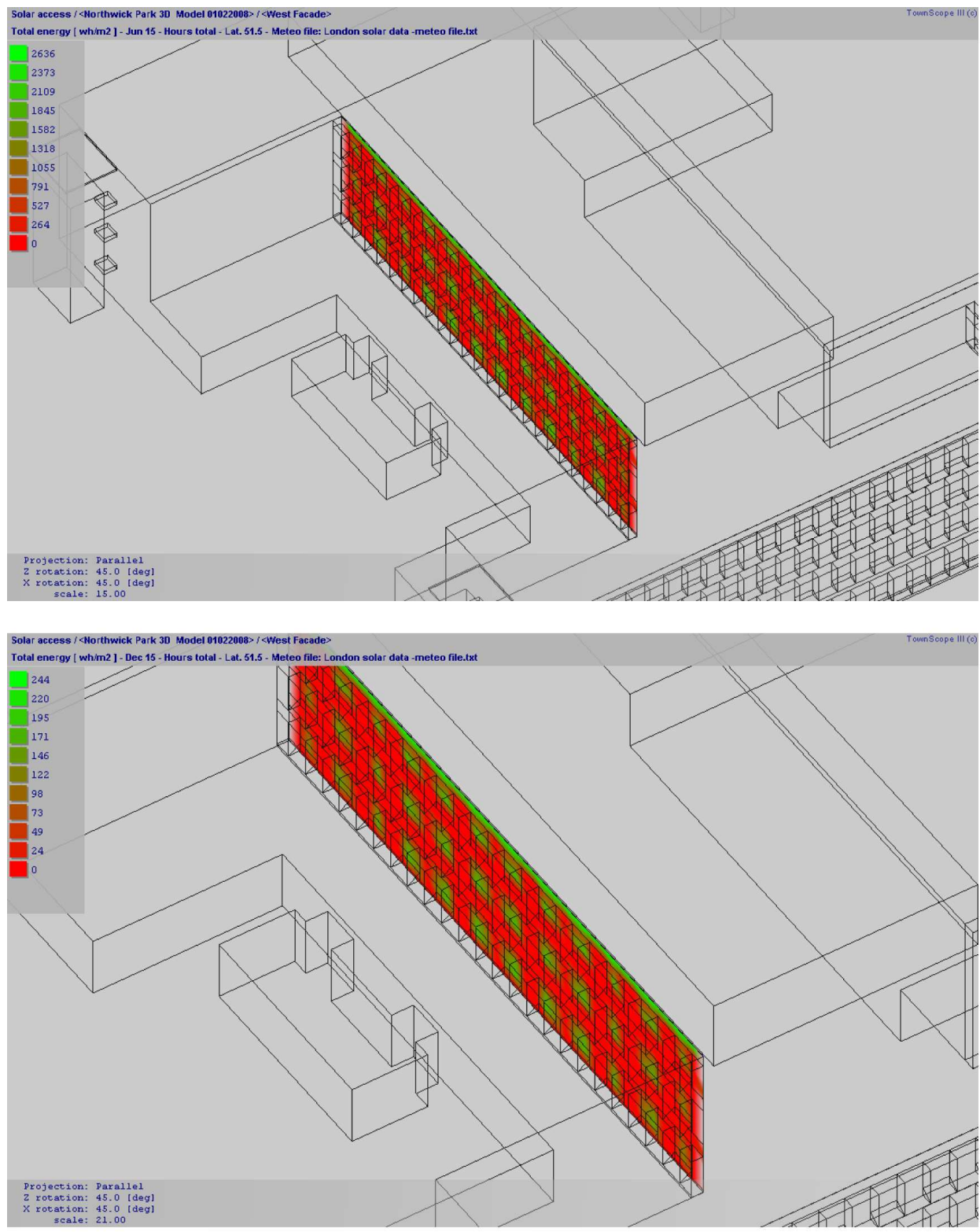

Figure 11

$147 \times 185 \mathrm{~mm}(300 \times 300$ DPI $)$

URL: http://mc.manuscriptcentral.com/tbps 


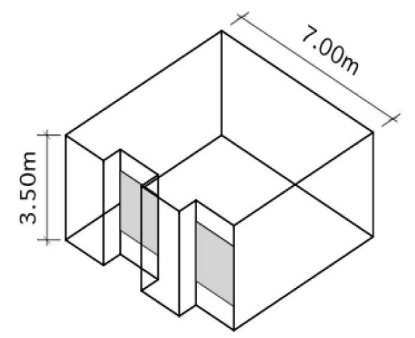

1 window height $\quad 2.00$ $\begin{array}{ll}\text { from floor } & 0.70 \\ \text { width } & 1.70\end{array}$
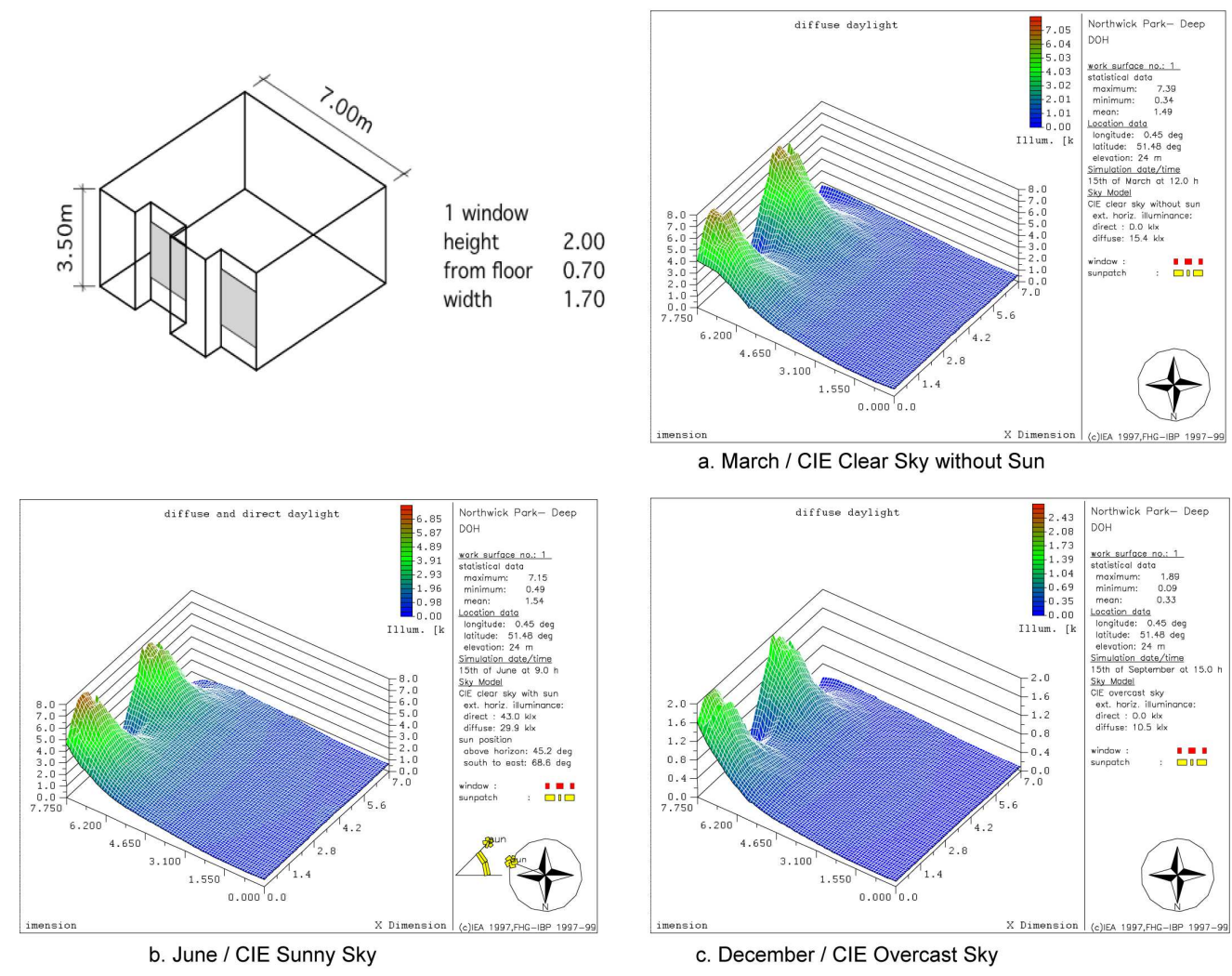

Figure 12

$182 \times 145 \mathrm{~mm}(300 \times 300$ DPI $)$ 


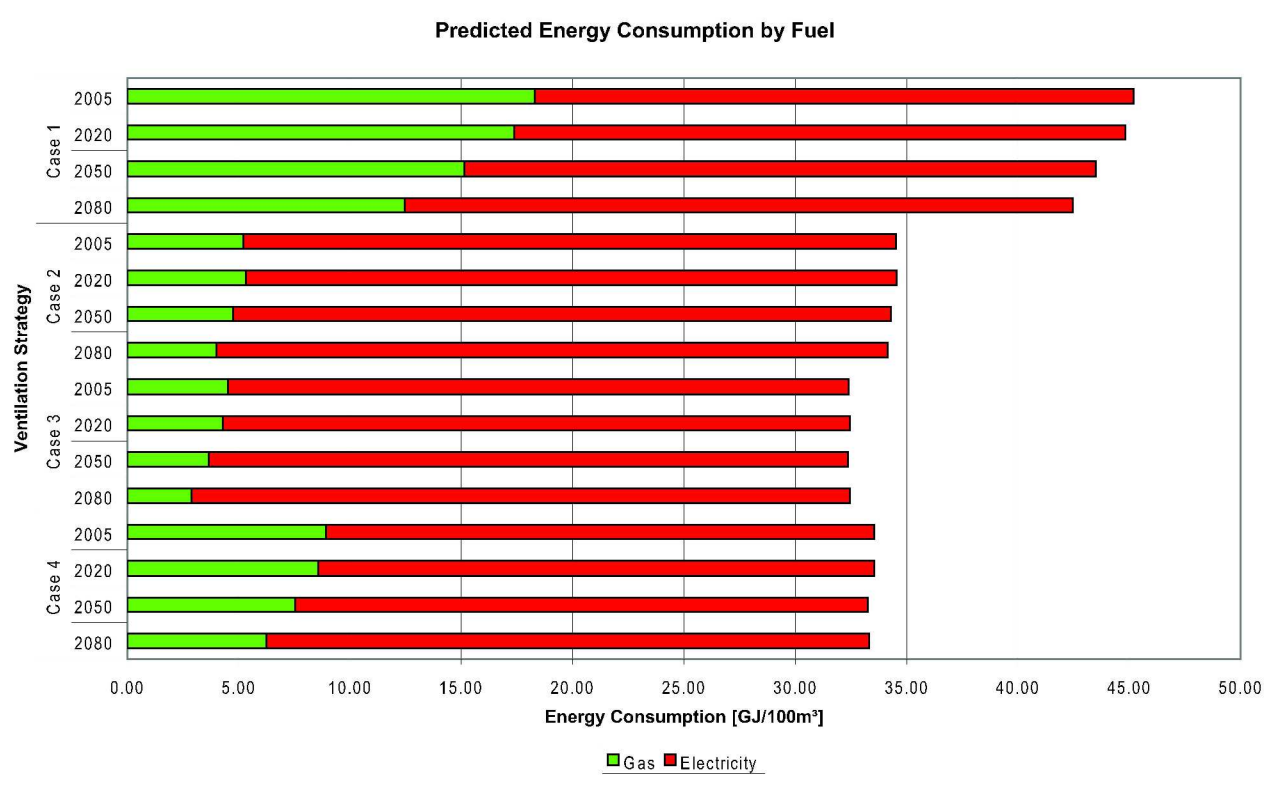

Figure 13

$258 \times 158 \mathrm{~mm}(600 \times 600$ DPI $)$ 


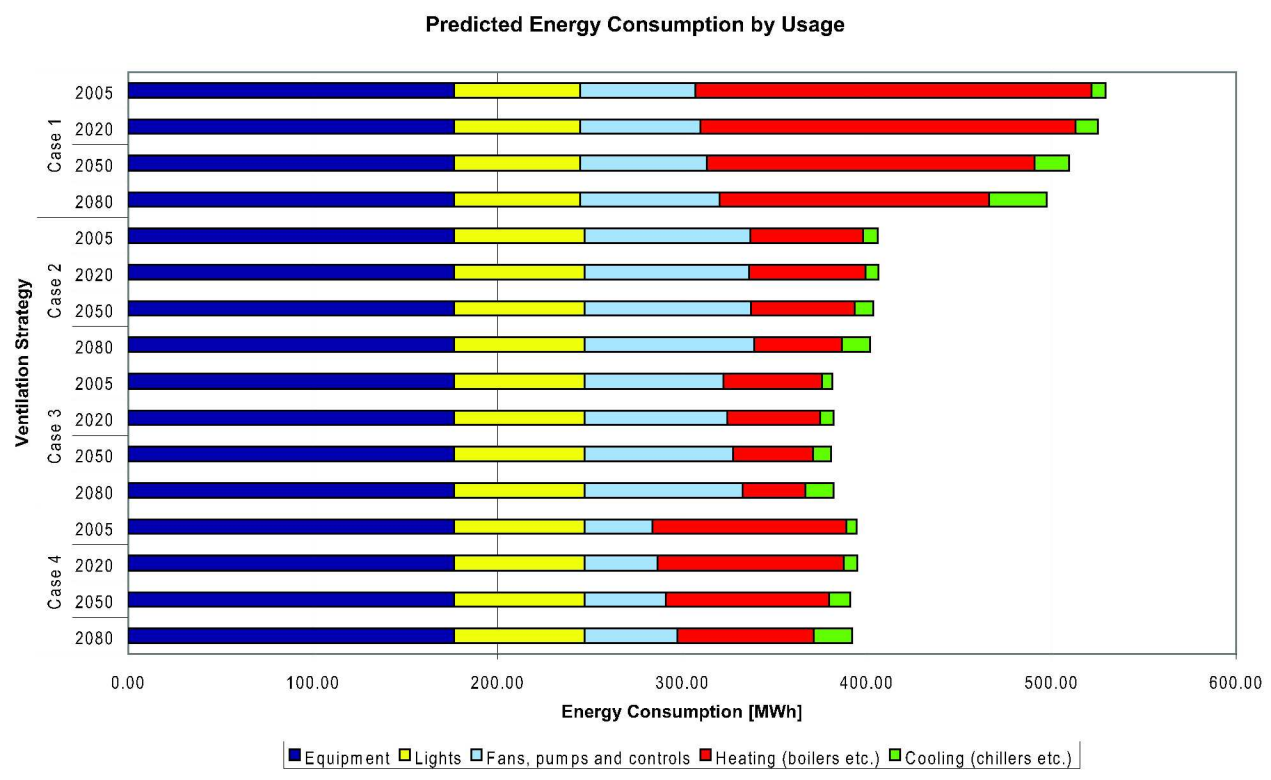

Figure 14

$258 \times 158 \mathrm{~mm}(600 \times 600 \mathrm{DPI})$ 


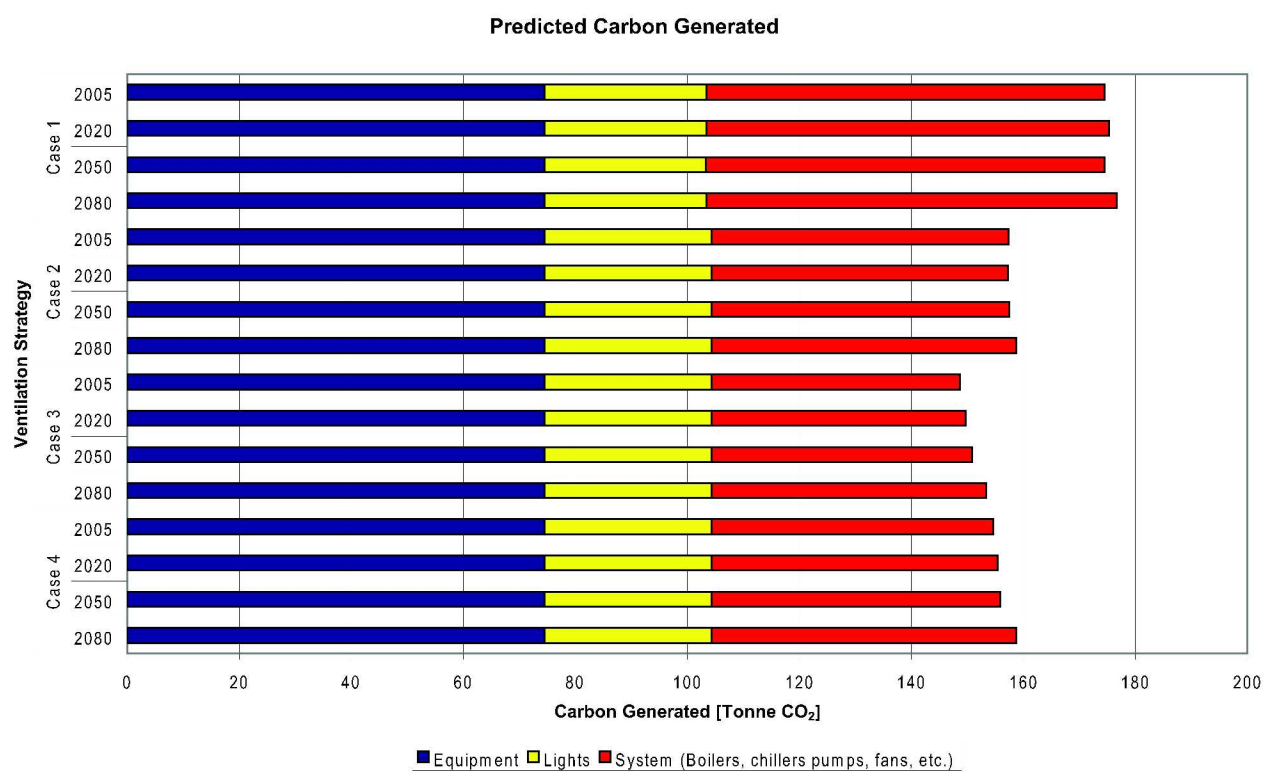

Figure 15

$258 \times 158 \mathrm{~mm}(600 \times 600 \mathrm{DPI})$ 